Cover: Background photograph shows radiotelemetry site on the Chehalis River, May 28, 2015. Photograph by Ryan G. Tomka, U.S. Geological Survey.

Inset photograph shows a radio-tagged spring Chinook salmon, June 19, 2014.

Photograph by John Serl, Washington Department of Fish and Wildlife. Used with permission. 


\section{Preliminary Evaluation of the Behavior and Movements of Adult Spring Chinook Salmon in the Chehalis River, Southwestern Washington, 2014}

By Theresa L. Liedtke, William R. Hurst, Ryan G. Tomka, Tobias J. Kock, and Mara S. Zimmerman

Prepared in cooperation with the Washington Department of Fish and Wildlife

Open-File Report 2017-1004

U.S. Department of the Interior

U.S. Geological Survey 


\section{U.S. Department of the Interior \\ SALLY JEWELL, Secretary}

\section{U.S. Geological Survey \\ Suzette M. Kimball, Director}

U.S. Geological Survey, Reston, Virginia: 2017

For more information on the USGS—-the Federal source for science about the Earth,

its natural and living resources, natural hazards, and the environment-visit

http://www.usgs.gov/ or call 1-888-ASK-USGS (1-888-275-8747).

For an overview of USGS information products, including maps, imagery, and publications, visit http://www.usgs.gov/pubprod/.

Any use of trade, firm, or product names is for descriptive purposes only and does not imply endorsement by the U.S. Government.

Although this information product, for the most part, is in the public domain, it also may contain copyrighted materials as noted in the text. Permission to reproduce copyrighted items must be secured from the copyright owner.

Suggested citation:

Liedtke, T.L., Hurst, W.R., Tomka, R.G., Kock, T.J., and Zimmerman, M.S., 2017, Preliminary evaluation of the behavior and movements of adult spring Chinook salmon in the Chehalis River, southwestern Washington, 2014: U.S. Geological Survey Open-File Report 2017-1004, 35 p., https://doi.org/10.3133/ofr20171004.

ISSN 2331-1258 (online) 


\section{Contents}

Abstract

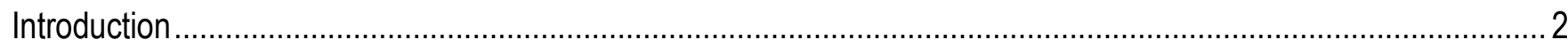

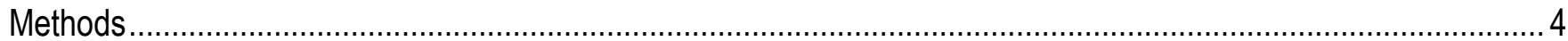

Study Site

Radio Transmitters........................................................................................................................

Fish Collection, Tagging, and Release .............................................................................................. 4

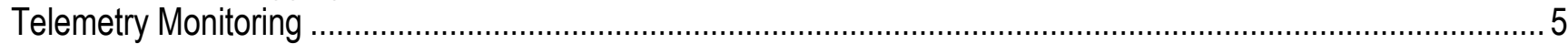

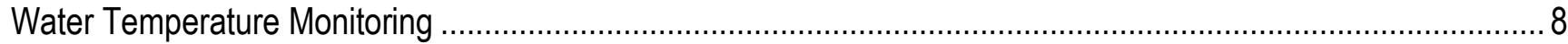

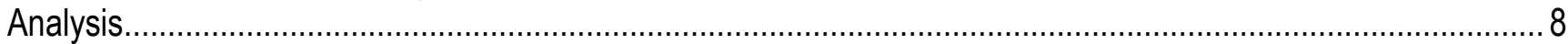

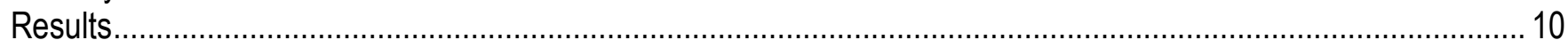

Fish Collection, Tagging, and Release ................................................................................................ 10

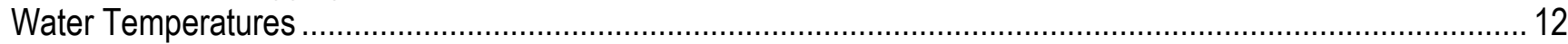

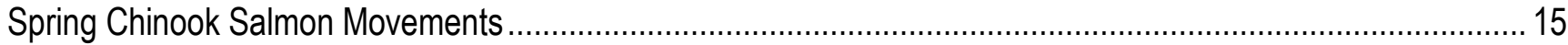

Spring Chinook Salmon and Water Temperatures................................................................................. 19

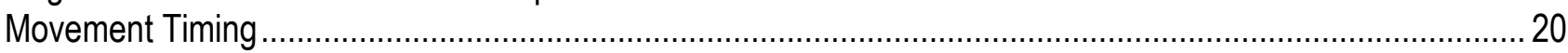

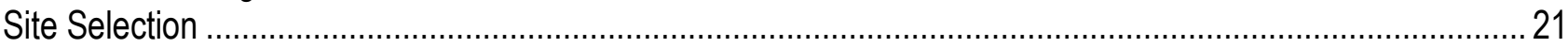

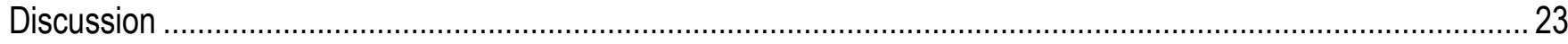

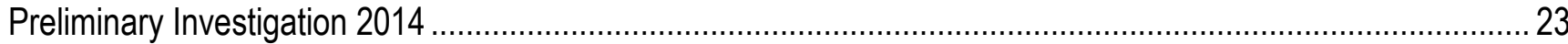

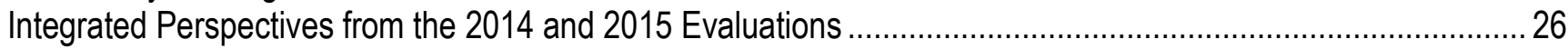

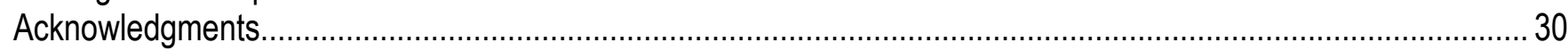

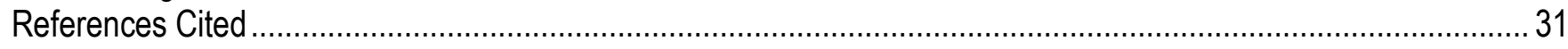

Appendix A. Water Temperatures in the Chehalis River, Southwestern Washington, Summer 2014 ..................... 33

\section{Figures}

Figure 1. Schematic showing locations of fixed-site telemetry monitoring stations and temperature loggers in the Chehalis River Basin, southwestern Washington, 2014

Figure 2. Graph showing water temperature on the main-stem Chehalis River, southwestern Washington, 1960-2014.

Figure 3. Graph showing monthly discharge on the main-stem Chehalis River, southwestern Washington, 1960-2014.

Figure 4. Graph showing maximum stream temperature by month in the subbasins of the Chehalis River Basin, southwestern Washington, March-September 2014

Figure 5. Daily maximum stream temperature in the subbasins of the Chehalis River Basin, southwestern Washington, March-September 2014. Data are mean of maximum daily temperature values.

Figure 6. Graph showing timing of movements for seven radio-tagged spring Chinook salmon, Chehalis River Basin, southwestern Washington, June-October 2014 


\section{Tables}

Table 1. Locations of the fixed site monitoring stations in the Chehalis River Basin, southwestern Washington, 2014

Table 2. Number of spring Chinook salmon collected, radio-tagged, and released, Chehalis River Basin, southwestern Washington, 2014......

Table 3. Statistics for all radio-tagged spring Chinook salmon monitored during the 2014 study period, Chehalis River Basin, southwestern Washington, 2014.

Table 4. Timing of first date of detection on fixed-location telemetry monitoring sites (fixed sites) for radio-tagged spring Chinook salmon captured and released in the Chehalis River Basin, southwestern Washington, 2014

Table 5. Mean selected water temperatures based on transmitter temperature sensor readings for radio-tagged spring Chinook salmon detected by fixed-site telemetry monitoring stations (fixed sites) in the Chehalis River, southwestern Washington, 2014

\section{Conversion Factors}

Inch/Pound to International System of Units

\begin{tabular}{llll}
\hline & Multiply & By & To obtain \\
\hline \multicolumn{4}{c}{ Length } \\
foot $(\mathrm{ft})$ & 0.3048 & meter $(\mathrm{m})$ & \\
mile $(\mathrm{mi})$ & 1.6093 & kilometer $(\mathrm{km})$ & \\
\hline
\end{tabular}

International System of Units to Inch/Pound

\begin{tabular}{|c|c|c|}
\hline Multiply & By & To obtain \\
\hline \multicolumn{3}{|c|}{ Length } \\
\hline millimeter (mm) & 0.03937 & inch (in.) \\
\hline centimeter $(\mathrm{cm})$ & 0.3937 & inch (in.) \\
\hline meter $(\mathrm{m})$ & 3.281 & foot (ft) \\
\hline kilometer (km) & 0.6214 & mile (mi) \\
\hline \multicolumn{3}{|c|}{ Salmon growth rate } \\
\hline millimeter per day $(\mathrm{mm} / \mathrm{d})$ & 0.03937 & inch per day (in/d) \\
\hline \multicolumn{3}{|c|}{ Mass } \\
\hline $\operatorname{gram}(\mathrm{g})$ & 0.03527 & ounce, avoirdupois (oz) \\
\hline
\end{tabular}

Temperature in degrees Celsius $\left({ }^{\circ} \mathrm{C}\right)$ may be converted to degrees Fahrenheit $\left({ }^{\circ} \mathrm{F}\right)$ as ${ }^{\circ} \mathrm{F}=\left(1.8 \times{ }^{\circ} \mathrm{C}\right)+32$.

\section{Datums}

Vertical coordinate information is referenced to the North American Vertical Datum of 1988 (NAVD 88)].

Horizontal coordinate information is referenced to the North American Datum of 1983 (NAD 83)]. 


\title{
Preliminary Evaluation of the Behavior and Movements of Adult Spring Chinook Salmon in the Chehalis River, Southwestern Washington, 2014
}

\author{
By Theresa L. Liedtke ${ }^{1}$, William R. Hurst ${ }^{1}$, Ryan G. Tomka' ${ }^{1}$, Tobias J. Kock¹, and Mara S. Zimmerman²
}

\begin{abstract}
Recent interest in flood control and restoration strategies in the Chehalis River Basin has increased the need to understand the current status and ecology of spring Chinook salmon (Oncorhynchus tshawytscha). Spring Chinook salmon have the longest exposure of all adult Chinook salmon life histories to the low-flow and high water temperature conditions that typically occur during summer. About 100 adult spring Chinook salmon were found dead in the Chehalis River in July and August 2009. Adult Chinook salmon are known to hold in cool-water refugia during warm summer months, but the extent to which spring Chinook salmon might use thermal refugia in the Chehalis River is unknown. A preliminary evaluation of the movements and temperature exposures of adult spring Chinook salmon following their return to the Chehalis River was conducted using radiotelemetry and transmitters equipped with temperature sensors. A total of 12 spring Chinook salmon were captured, radio-tagged, and released in the main-stem Chehalis River between May and late June 2014. Tagged fish were monitored from freshwater entry through the spawning period using a combination of fixedsite monitoring locations and mobile tracking.

Water temperature and flow conditions in the main-stem Chehalis River during 2014 were atypical compared to historical averages. Mean monthly water temperatures between March and August 2014 were higher than any decade since 1960 and mean monthly discharge was 90-206 percent of the discharge in previous years. Overall, 92 percent of the tagged fish were detected, with a mean of $102 \mathrm{~d}$ in the detection history of tagged fish. Seven tagged fish (58 percent) moved upstream, either shortly after release (5-8 d, 57 percent), or within about a month (34-35 d, 29 percent). One fish (14 percent) remained near the release location for $98 \mathrm{~d}$ before moving upstream. The final fates for the seven fish that moved upstream following release included six fish that were assigned a fate of spawner and one fish with an unknown fate. Tagged fish showed limited movements during the peak water temperatures in July and August, and were not frequently detected at sites where water temperatures exceeded $21^{\circ} \mathrm{C}$. The mouths of the Skookumchuck and Newaukum Rivers were commonly used by tagged fish for extended periods during peak water temperatures and study fish with a fate of spawner were last detected in these tributaries.
\end{abstract}

\footnotetext{
${ }^{1}$ U.S. Geological Survey.

${ }^{2}$ Washington Department of Fish and Wildlife.
} 
This pilot study represents a substantial contribution to the understanding of spring Chinook salmon in the Chehalis River Basin, and provides information for the design and execution of future evaluations. The water temperatures and flow conditions during the 2014 study period were not typical of the historical conditions in the basin and the numbers of tagged fish monitored was relatively low, so results should be interpreted with those cautions in mind.

\section{Introduction}

Chinook salmon (Oncorhynchus tshawytscha) have diverse life histories in both freshwater and marine environments (Healey, 1991; Quinn, 2011). One aspect of this diversity is the timing of adult return to freshwater prior to spawning. Populations of Chinook salmon are named according to this return timing (spring-run, summer-run, fall-run, winter-run) and often coexist in the same river systems. The diversity of Chinook salmon is the focus of several ongoing research studies in the Chehalis River Basin in southwestern Washington. The Chehalis River is a low-gradient river (maximum elevation about $984 \mathrm{ft}$ or about $300 \mathrm{~m}$ ) flowing through the central coast of Washington and is characterized by rain-dominant hydrology. Recent interest in flood control and restoration strategies in this basin has increased the need to understand the current status and ecology of aquatic species in the basin (Aquatic Species Enhancement Plan Technical Committee, 2014). Key questions regarding the status of Chinook salmon include understanding spatial and temporal overlap among life histories, predicting responses to proposed flood control and restoration strategies, and anticipating climate change impacts.

Spring-run (hereafter spring) Chinook salmon have the longest exposure of all adult Chinook salmon life histories to low flow and warm water conditions that typically occur during summer months because they return to freshwater during the spring but do not spawn until late summer or early fall. Spring Chinook salmon return to freshwater 3-7 months prior to spawning (Healey, 1991) and can experience both sublethal and lethal effects if their thermal environment is too warm. Adult Chinook salmon are known to hold in cool-water refugia to reduce metabolic costs during warm summer months (Berman and Quinn, 1991; Torgersen and others, 1999; Goniea and others, 2006). Metabolic costs after returning to freshwater include basal metabolic rate, migration to the spawning grounds, gamete maturation, and spawning. Adult salmon do not feed in freshwater, and the energetic costs of metabolism and migration influence energetic reserves available for gamete maturation and spawning (Hearsey and Kinziger, 2015; Quinn and others, 2015). Generally, stream temperatures can influence gamete development and viability of salmon and trout (Smith and others, 1983; Berman, 1990). Berman and Quinn (1991) calculated that a $2-5^{\circ} \mathrm{C}$ decrease in temperature would be associated with a 25 percent reduction in basal metabolic rate of spring Chinook salmon in the Yakima River. Such a reduction in metabolic rate conserves energy for gamete development and spawning. Stream temperatures exceeding $21^{\circ} \mathrm{C}$ have been observed to halt the upstream migration of adult salmon (Richter and Kolmes, 2005), including spring Chinook salmon in the Columbia River Basin (Alabaster, 1988; Dauble and Mueller, 1993). Lethal temperatures for adult spring Chinook salmon are reported as between 24 and $26^{\circ} \mathrm{C}$ (Sullivan and others, 2000; Richter and Kolmes, 2005) and may depend on a number of factors including previous acclimation temperatures and duration of exposure. Sublethal effects also depend on these factors, and can influence fish at lower temperatures. 
Thermal heterogeneity in rivers may occur at large spatial scales due to elevational gradients (Rahel and Hubert, 1991; Rieman and McIntyre, 1995) or more local scales due to tributary inputs, groundwater seeps, shading, or vertical stratification (Ebersole and others, 2003; Caissie, 2006; Tiffan and others, 2009; Dugdale and others, 2015). In the Chehalis River, the availability of suitable water temperature and habitat for adult spring Chinook salmon is a particular conservation concern. Adult spring Chinook salmon are exposed to multiple environmental stressors during their summer holding period including low flows, warm temperatures, and low oxygen levels. These stressors are a natural product of the rain-dominant hydrology but have also been exacerbated by historical and current land use, including water withdrawals and removal of riparian vegetation (Smith and Wenger, 2001). Elevated water temperatures can directly affect fish survival. For example, fish kills of adult Chinook salmon in the Chehalis River were observed in late July and early August 2009 (Mike Kohn, Lewis County Public Utility District, written commun., 2009). During this event, approximately 100 adult spring Chinook salmon were found dead at several locations in the river, including river mile 74 and 104 of the main-stem Chehalis River and in the lower Newaukum River downstream of the confluence of the north and south forks. Water temperatures obtained from the fish kill locations by Lewis County Public Utility District on August 3 and 4, 2009 (several days after the fish kill event) exceeded $21.0{ }^{\circ} \mathrm{C}$; however, little is known about the water temperatures prior to the fish kill or the exposure histories of the fish.

A better understanding of spring Chinook salmon in the Chehalis River will expand our general understanding of factors contributing to Chinook salmon life history diversity. Specifically, more information is needed on the behavior and associated temperature exposures of adult spring Chinook salmon during their freshwater residency in the Chehalis River. The extent to which these fish might use thermal refugia or other temperature mitigation strategies in the Chehalis River is currently (2016) unknown. This understanding will inform the types of habitat protection and fish management actions that will help to preserve the long-term diversity of Chinook salmon in the basin.

The objectives of this preliminary evaluation were to describe the movements and temperature exposures of adult spring Chinook salmon following their return to the Chehalis River. We used radio transmitters equipped with a temperature sensor to allow us to monitor movement patterns and water temperature exposures and temperature selections of tagged fish during their freshwater residency. This technique was previously used by Berman and Quinn (1991) to evaluate similar factors for spring Chinook salmon in the Yakima River, Washington. The general lack of information about spring Chinook salmon movements and distribution in the Chehalis River prior to spawning was the largest challenge to the design and execution of this study. We hoped to collect some basic information such as where and when fish might aggregate and hold in order to allow them to be collected for tagging and to position our monitoring stations. Using this basic information, future evaluations of spring Chinook salmon in the Chehalis River will be able to make substantial contributions to the needs of managers in this basin. 


\section{Methods}

\section{Study Site}

The Chehalis River Basin in southwestern Washington has a drainage area of about $6,900 \mathrm{~km}^{2}$, or about 2,664 $\mathrm{mi}^{2}$ (Smith and Wenger, 2001). Subbasins within the basin drain from the Willapa Hills, foothills of the Cascade Mountains, and the Olympic Mountains. The river terminates in Grays Harbor, an estuary of the Pacific Ocean, near Aberdeen, Washington. Land uses include commercial forest, agriculture, and urban development (Hiss and Knudsen, 1993). The rain-dominant hydrology of the Chehalis River Basin is characterized by peak flows during winter and low flows during summer. The Chehalis River supports a diversity of native fish species including steelhead (Oncorhynchus mykiss), cutthroat trout (O. clarkii), Chinook salmon, coho salmon (O. kisutch), and chum salmon (O. keta). Stock assessment of these populations includes spawning ground surveys conducted annually by the Washington Department of Fish and Wildlife, Quinault Indian Nation, and Confederate Tribes of the Chehalis Reservation. Few studies have monitored fish distribution prior to the spawning period. Evaluations of fish distribution and ecology in the Chehalis River have largely focused on use of offchannel and estuarine habitats (Moser and others, 1991; Fresh and others, 2003; Henning and Schirato, 2006; Henning and others, 2007; Kuehne and Olden, 2016).

\section{Radio Transmitters}

The transmitters used for the study were manufactured by Lotek Wireless, Inc. (Newmarket, Ontario, Canada), model MCFT2-3EM. The tags were $52 \mathrm{~mm}$ long, with a diameter of $12 \mathrm{~mm}$, and weighed $10 \mathrm{~g}$ in air. The battery of the tag was designed to provide a minimum of 419 days of tag life, with an average tag life of 523 days. Each tag was equipped with a sensor that measured water temperature from -6 to $34{ }^{\circ} \mathrm{C}$ and was specified by the manufacturer to be accurate to $\pm 0.8^{\circ} \mathrm{C}$. Once every 5 seconds, each tag emitted a signal that transmitted a unique tag identification and water temperature data. Controlled laboratory testing of the transmitter's temperature sensor was conducted as part of a parallel study in 2015 (Liedtke and others, 2016).

All tags operated on a single frequency (167.400 MHz). Throughout the report, tags are reported as unique tag IDs using two digits of the frequency along with the unique code for a given transmitter. For example, tag ID 40033 is code 033 on frequency $167.400 \mathrm{MHz}$. In addition to using tag IDs, each study fish was assigned a number (1-12) to increase readability in this report.

\section{Fish Collection, Tagging, and Release}

Little information was available on where and when adult spring Chinook salmon might be captured for tagging, making collection of fish one of the most challenging aspects of this study. We consulted with local fishermen and local guides to inform our collection efforts, including timing, locations, and capture gear. Another challenge to the study design and fish collection was the limited information available on the run timing for spring Chinook salmon in the system, specifically related to the timing of freshwater entry. 
Hook-and-line angling was the only capture method used to collect fish. Angling was conducted from a drift or jet boat on the main-stem Chehalis River from river mile (RM) 69.0 (Borst Park boat launch near the mouth of the Skookumchuck River) to RM 16.2 (mouth of the Wynoochee River), beginning in late May 2014. Within this reach, angling efforts were focused on known Chinook salmon holding areas using the expertise and assistance of local fishermen and fishing guides. All fish collection and tagging efforts were terminated in late June due to concerns over handling fish at high water temperatures. Data recorded on the collection effort included date, river water temperature, sex, fork length, hook location, and fish condition.

Fish handling procedures aimed to minimize exposure to air, keep fish in cool, well oxygenated water, and minimize disturbances (Kelsh and Shields, 1996). Tagging and release procedures were conducted at the sites where fish were collected. After capture, fish were either transferred from the river into an insulated container $(390 \mathrm{~L})$ filled with river water using a net (hoop dimensions $94 \times 102$ $\mathrm{cm}$ ), or fish were held in flowing river water in a net to conduct initial examinations and tagging. The condition of the fish was examined and fish were rejected if they appeared lethargic, bled heavily from the hook location, or were otherwise negatively affected by capture.

Once a captured fish was selected for tagging, a glycerin-coated tag was inserted gastrically using techniques described by Keefer and others (2004). Prior to tag insertion each transmitter was fitted with a single band of silicon surgical tubing (about $5 \mathrm{~mm}$ wide; $3 \mathrm{~mm}$ thick; $10 \mathrm{~mm}$ inside-diameter) to increase roughness and reduce the likelihood of transmitter regurgitation. Fish were submerged in river water throughout the tagging process. The recorded tagging data included tag ID and tagger name.

Following tag insertion fish were removed from the holding container or net and returned directly to the river for recovery. During recovery, fish were gently grasped by the caudal peduncle and oriented with their heads facing upstream. At this time, tag placement and fish condition were evaluated by visual observation. Fish were released after they demonstrated a strong resistance to restraint, usually after less than 5 minutes of recovery. Fish showing limited resistance, or those that were generally lethargic, were not used in the study; the inserted tags were removed and the fish were released. Data recorded at the time of release included release location and release time.

\section{Telemetry Monitoring}

A combination of fixed-site radiotelemetry monitoring stations and mobile tracking efforts were used to collect information on the behavior, movement patterns, and temperature selection of tagged fish within the study area (fig. 1). The goals of the monitoring efforts were to identify the timing of fish movements through the main-stem Chehalis River, identify holding locations, and record water temperatures selected by tagged fish during their migration. The array of fixed-site monitoring locations (hereinafter "fixed sites") included eight sites, beginning at RM 6.1 on the Chehalis River and continuing to RM 111 (table 1). Each fixed site included a telemetry receiver tuned to monitor the frequency of the transmitters, an aerial antenna (or a combination of antennas), and a power source to supply the receiver. The goal of the fixed site array was to partition the main-stem Chehalis River into sections in order to detect relatively large-scale fish movements (on the order of several $\mathrm{km}$ ) and the timing of those movements. Fixed sites were placed low in the system (RM 6.1) and high in the system (RM 111) in an effort to capture the largest possible range of fish movements. Fixed sites between the lowest and the highest sites were positioned without any background information on where fish might aggregate or hold as that information was not available. 


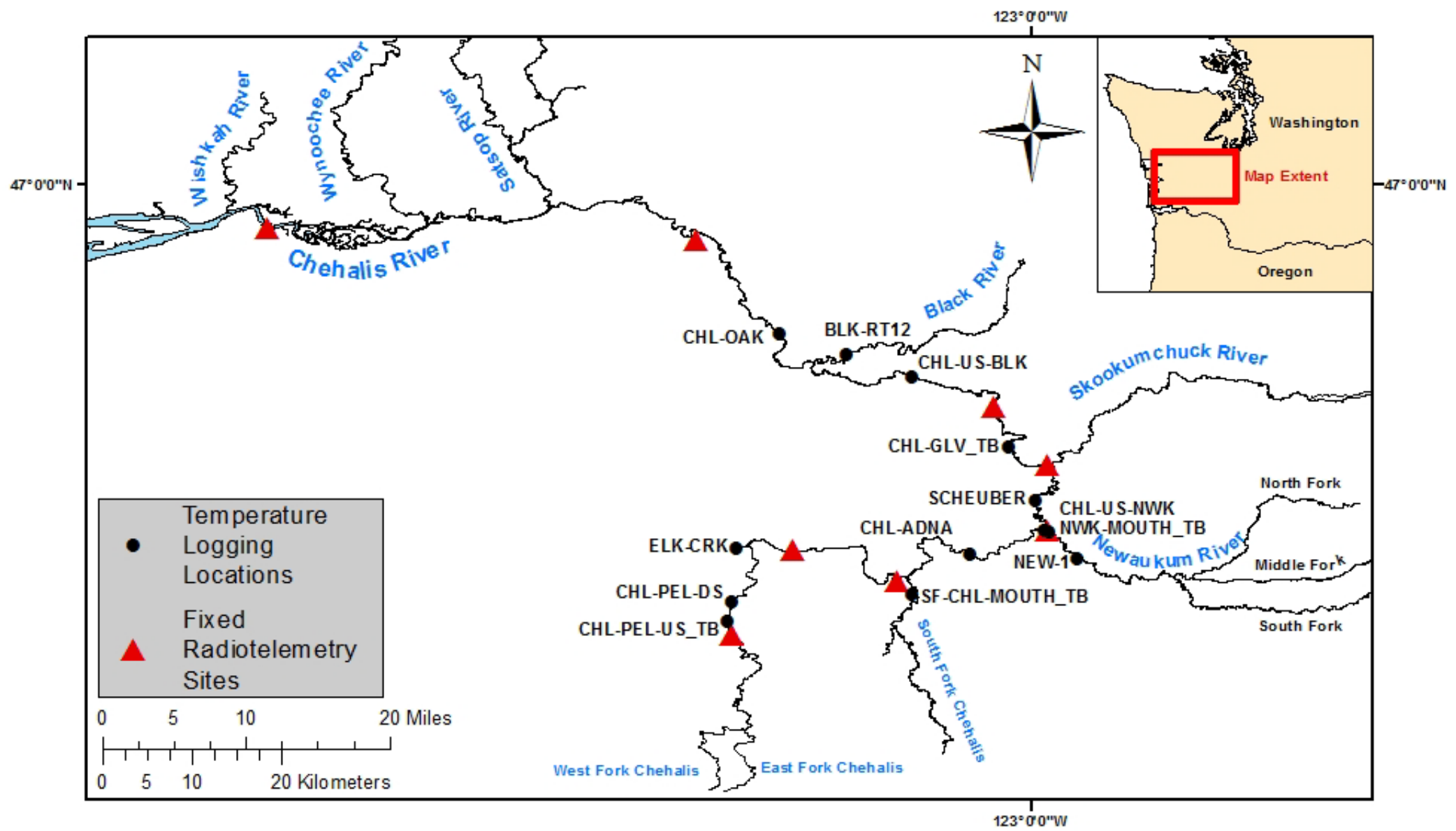

Figure 1. Schematic showing locations of fixed-site telemetry monitoring stations and temperature loggers in the Chehalis River Basin, southwestern Washington, 2014. 
Table 1. Locations of the fixed site monitoring stations in the Chehalis River Basin, southwestern Washington, 2014.

[Locations are referenced based on river miles from the mouth of the Chehalis River. RM, river mile; WA, Washington]

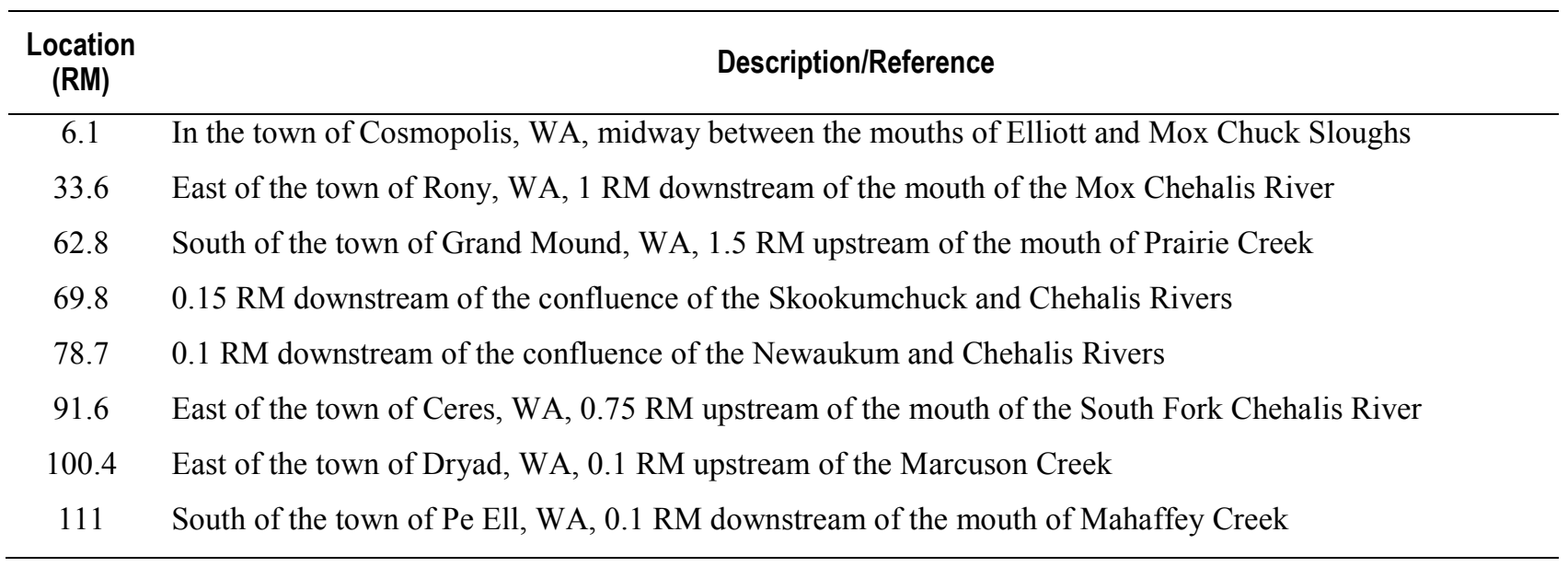

Seven of the eight fixed sites were installed in late April 2014. The fixed site located near the mouth of the Skookumchuck River was installed on September 3, 2014, after several tagged fish were repeatedly detected in close proximity to the river's mouth during mobile tracking surveys. After installation, fixed sites were operated continuously until they were removed on October 23, 2014. The fixed sites were visited regularly to maintain effective operation and to secure data recorded on the receivers.

Mobile tracking was used to identify fish locations and temperature selections in areas not monitored by fixed sites. Mobile tracking was conducted from May to October 29, 2014, with weekly surveys conducted after the first week of July. Tracking efforts were focused on areas with previous mobile detections of tagged fish and on areas identified as potential fish locations based on reports generated from the fixed sites. Tracking was conducted with a hand-held radiotelemetry receiver and an aerial antenna. Once a fish was detected, the tracker moved toward the fish location while lowering the gain on the receiver to refine the fish position. Once the tracker was as close to the fish as possible, information was recorded regarding date, time, transmitter's temperature sensor reading, location (latitude, longitude with GPS), and a general location description relative to known landmarks. In a few instances, the mobile tracker collected a surface water temperature near the estimated location of the tagged fish in order to make comparisons between the ambient river temperature near the fish location and the temperature reported by the tag's sensor. 


\section{Water Temperature Monitoring}

Digital thermographs, or temperature loggers, were installed and operated by the U.S. Geological Survey, Washington Department of Fish and Wildlife, and Washington Department of Ecology at 13 locations in 2014 (fig. 1). As this was a preliminary evaluation, the study relied heavily on existing efforts to monitor water temperatures in the Chehalis River Basin, for which deployment locations and timing had previously been established. Six of the 13 temperature loggers monitored temperatures along the main-stem Chehalis River, beginning near the town of Oakville, Washington (RM 45.2) and continuing upstream to the town Adna, Washington (RM 85.1). Two loggers were deployed near the town of Pe Ell, Washington at RM 107 and RM 110, and results from these loggers were used to depict conditions from the upper Chehalis River subbasin. Water temperature loggers were also deployed in the Black River, the lower Newaukum River, Elk Creek, and South Fork Chehalis River subbasins (fig. 1). Temperature loggers were deployed in the lower Skookumchuck River, but repeated unauthorized removal of the loggers prevented the collection of useful water temperature data. Daily maximum and minimum water temperature data collected at the hatchery located near the Skookumchuck Dam, at RM 22 were also available for analysis.

Temperature loggers (Onset Hobo ${ }^{\circledR}$ Pendant 64K, Onset Computer Corporation, Bourne, Massachusetts, accuracy $\pm 0.5^{\circ} \mathrm{C}$ ) collected stream temperature data at 5- or 30-minute intervals. As the loggers were deployed by a variety of agencies, and set-up and deployment were not pre-arranged for this evaluation, the data collection interval was not consistent. The loggers were secured in white plastic vinyl carbonate (PVC) housings with openings that allowed flowing water to contact the logger.

Loggers were positioned in flowing water out of direct sunlight. The accuracy of each logger was compared to a National Institute of Standards and Technology (NIST) reference thermometer prior to being deployed and were confirmed to be within specifications.

\section{Analysis}

Fish movements were summarized from a dataset that combined all fixed site and mobile tracking detections for each individual study fish. Fixed site detections prior to the recorded time of release and those with low signal strength $(<100)$ were removed from the detection dataset. A detection history was generated for each study fish and was used to summarize fish movements.

The timing of fish movements, residence time at a fixed site, and the maximum displacement from the release location were summarized. Fish location (by river mile) was plotted by date in the main-stem Chehalis River as spring Chinook salmon migrated upstream and were detected at the fixed sites. This summary showed the rate at which fish moved through the river and any areas of extended holding between fixed sites during the study period. The residence time at a fixed site was expressed as the difference between the first date and time of detection at a fixed site and the last date and time of detection at the same fixed site. The maximum displacement for individual fish was calculated as the distance between the release location and the detection location that was the furthest away from the release location. The mean maximum displacement was reported, along with the lowest and highest maximum displacement distance. 
Water temperatures experienced by tagged fish were summarized based on tag temperature sensor data collected by the fixed sites or during mobile tracking surveys. Tag temperature sensor data were carefully reviewed before analyses were conducted. Data from the sensor were used for analyses if the signal strength for the detection record was high $(>100)$, there were several similar readings within a short time period (minutes), and the temperature was reasonable (within about $5{ }^{\circ} \mathrm{C}$ ) when compared to the ambient water temperature near where the tag was located. If sensor data failed to meet these criteria they were removed from the temperature dataset and were not included in any analyses of fish temperature exposure or selection. Finally, if the tag was documented to have been removed from the water (for example, harvested, predated, or in a dead fish), the sensor data were not used for analyses since the specific timing of removal could not be confirmed.

Temperature selection by tagged fish was examined by comparing the tag temperature sensor data to measures of ambient river temperature as recorded by the array of water temperature loggers deployed throughout the study area. Tag temperature sensor data were combined with ambient river temperature data using the detection history for a given fish which provided a location, date, and time for each detection. The water temperature logger nearest a given fish detection was used to represent the ambient water temperature. For fish detected by a fixed site, the tag sensor temperature was averaged over the period of time that the fish was detected at the site (residence time) and matched with the same time period at the closest temperature logger. For each mobile tracking detection, the tag sensor temperature was a single value. Using the date and time of the tag temperature sensor record, the average temperature recorded by the nearest water temperature logger was calculated for the period 30 min prior to and after the fish detection.

Each tagged fish was assigned a final fate based on the detection history. Four potential fate categories were defined: spawner, spit/mortality, pre-spawn mortality, and unknown. A fate of spawner was assigned if a fish was known to survive to the spawning period (defined as starting September 1, 2014) and was located in a potential spawning area during the spawning period. A fate of spit/mortality was assigned to fish with little evidence of movement after tagging, or a documented mortality. As the tags were gastrically implanted into study fish, they could have been regurgitated or "spit." A spit tag will commonly fall to the bottom of the river and remain relatively stationary, generating a detection history similar to that of a dead fish. This fate assignment suggests that fish had a negative response to capture, handling, or tagging, leading to death or a spit tag, or the fish died of natural causes some time prior to spawning. A pre-spawn mortality fate was assigned if there was evidence that the fish and (or) the tag were actively removed from the river during the study period, either through a predation or a harvest event (for example, if the tag was recovered above the waterline on the riverbank). In one case the fish was confirmed to have been harvested by a tribal fishing net. Finally, a fate of unknown was assigned to fish where information was lacking to provide evidence for any other fate. 


\section{Results}

\section{Fish Collection, Tagging, and Release}

In total, 12 adult spring Chinook salmon were tagged and released for this study (table 2). Spring Chinook salmon were collected and tagged from late-May to late-June 2014. The primary goal for fish collection efforts was to capture fish as low in the Chehalis River as possible so that their upstream movements and timing could be monitored. Two fish were captured and released near the town of South Elma, Washington at RM 28.3 and 31.4. One fish was captured and released near RM 34.9. Three fish were captured and released near the mouth of Cedar Creek at RM 41.8 (two fish) and RM 42.1 (one fish). Four fish were captured and released upstream of the mouth of Cedar Creek at RM 43.2. One fish was captured and released near the mouth of Prairie Creek at RM 60.8, and one fish was captured and released near the mouth of Scammon Creek at RM 69. Of the 12 fish tagged during this study, 7 were visually estimated to be females, 4 were estimated to be males, and 1 was of undetermined sex (table 2). The mean fork length of tagged fish was $72 \mathrm{~cm}$, with a minimum fork length of $38 \mathrm{~cm}$, and a maximum fork length of $90 \mathrm{~cm}$ (table 3 ).

Table 2. Number of spring Chinook salmon collected, radio-tagged, and released, Chehalis River Basin, southwestern Washington, 2014.

[Details include the date fish were collected, tagged, and released, the number of fish tagged on each date, the capture and release location (by river mile), and the sex of the fish]

\begin{tabular}{cccc}
\hline Date & Number of fish tagged & $\begin{array}{c}\text { Capture/release } \\
\text { river mile }\end{array}$ & Sex \\
\hline May 22, 2014 & 1 & 60.8 & 1 female \\
June 11, 2014 & 1 & 69.0 & 1 female \\
June 18, 2014 & 1 & 42.1 & 1 undetermined \\
June 19, 2014 & 4 & 43.2 & 1 female, 3 male \\
June 24, 2014 & 1 & 28.3 & 1 male \\
June 24, 2014 & 1 & 31.4 & 1 female \\
June 24, 2014 & 1 & 34.9 & 1 female \\
June 24, 2014 & 1 & 41.8 & 1 female \\
June 25, 2014 & 1 & 41.8 & 1 female \\
\hline Total & 12 & & 7 female, 4 male, 1 \\
\end{tabular}


Table 3. Statistics for all radio-tagged spring Chinook salmon monitored during the 2014 study period, Chehalis River Basin, southwestern Washington, 2014.

[Details include the tag ID, fish number, the release location (river miles as measured from the mouth of the Chehalis River), release date, fork length (FL), sex, number of fixed sites that detected fish, number of times fish was detected by mobile tracking, last known location (SFN, South Fork Newaukum River), last date of detection, number of days in the detection history of the fish (days between the release date and the last date of detection), and the fate assigned to the fish based on the detection history. F, female; U, unknown; M, male]

\begin{tabular}{|c|c|c|c|c|c|c|c|c|c|c|c|}
\hline$\underset{\text { ID }}{\text { Tag }}$ & $\begin{array}{c}\text { Fish } \\
\text { number }\end{array}$ & $\begin{array}{l}\text { Release } \\
\text { location } \\
\text { (RM) }\end{array}$ & $\begin{array}{l}\text { Release } \\
\text { date }\end{array}$ & $\begin{array}{c}\mathrm{FL} \\
(\mathrm{cm})\end{array}$ & Sex & $\begin{array}{c}\text { Fixed site } \\
\text { summary } \\
\text { (number of sites } \\
\text { detected) }\end{array}$ & $\begin{array}{l}\text { Mobile tracking } \\
\text { summary (number } \\
\text { of detections) }\end{array}$ & Last known location & Late date detected & $\begin{array}{l}\text { Number of } \\
\text { days in } \\
\text { detection } \\
\text { history }\end{array}$ & Fate \\
\hline 40033 & 1 & 60.8 & May 22 & 77 & $\mathrm{~F}$ & 0 & 10 & Near release site & October 12 & 144 & Spit/mort \\
\hline 40036 & 2 & 69.0 & June 11 & 75 & $\mathrm{~F}$ & 1 & 5 & $\begin{array}{c}\text { Skookumchuck RM } \\
21.6\end{array}$ & October 20 & 132 & Spawner \\
\hline 40039 & 3 & 42.1 & June 18 & 71 & $\mathrm{U}$ & 0 & 0 & Chehalis RM 48 & NA & 0 & Harvested \\
\hline 40004 & 4 & 43.2 & June 19 & 68 & $\mathrm{~F}$ & 3 & 14 & $\begin{array}{c}\text { Skookumchuck } \\
\text { mouth }\end{array}$ & October 22 & 126 & Spawner \\
\hline 40006 & 5 & 43.2 & June 19 & 38 & M & 3 & 11 & SFN RM 5.4 & October 29 & 133 & Spawner \\
\hline 40007 & 6 & 43.2 & June 19 & 80 & $\mathrm{M}$ & 2 & 1 & Chehalis RM 48 & October 20 & 124 & Unknown \\
\hline 40008 & 7 & 43.2 & June 19 & 62 & M & 2 & 12 & Newaukum RM 1.4 & October 29 & 133 & Spawner \\
\hline 40005 & 8 & 28.3 & June 24 & 72 & $\mathrm{M}$ & 4 & 13 & SFN RM 17.8 & October 29 & 128 & Spawner \\
\hline 40013 & 9 & 41.8 & June 24 & 90 & $\mathrm{~F}$ & 0 & 17 & Near release site & October 21 & 120 & Spit/mort \\
\hline 40021 & 10 & 31.4 & June 24 & 79 & $\mathrm{~F}$ & 0 & 12 & Near release site & October 12 & 111 & Spit/mort \\
\hline 40035 & 11 & 34.9 & June 24 & 76 & $\mathrm{~F}$ & 1 & 0 & Chehalis RM 33.6 & June 24 & 1 & Unknown \\
\hline 40015 & 12 & 41.8 & June 25 & 71 & $\mathrm{~F}$ & 2 & 1 & $\begin{array}{c}\text { Skookumchuck } \\
\text { mouth }\end{array}$ & September 6 & 74 & Spawner \\
\hline
\end{tabular}




\section{Water Temperatures}

The water temperatures in the main-stem Chehalis River during summer 2014 were atypical compared to historical averages. The mean monthly water temperatures between March and August 2014 were higher than any decade since 1960 (fig. 2). The water temperatures were above average beginning early in the spring, and this trend continued through August (fig. 2). The mean monthly temperatures observed in the main-stem Chehalis River between May and August 2014 were $0.2-4.4^{\circ} \mathrm{C}$ higher than water temperatures observed in previous decades. Mean monthly discharge in the main-stem Chehalis River during the spring 2014 was 90-206 percent of historical discharge observed during the same time period in previous years (fig. 3). Although the discharge was higher than normal during the spring (March through May), during June, July, and August, mean monthly discharge was fairly typical compared to historical data. The observed discharge during this period was 50-134 percent of the discharge observed in a similar time frame in previous years (fig. 3).

A summary of stream temperature metrics for each temperature logger site is provided in appendix 1. Several logger sites had periods during the study when data were not available. For this preliminary evaluation, the effort to monitor water temperatures in the basin was still in the coordination stage, and deployment schedules for many loggers were based on the timing for other research efforts. Additionally, our logger array was impacted by vandalism and theft. Efforts were made to redeploy new loggers following those events, but some data gaps remain.

Maximum daily water temperatures along the main-stem Chehalis River exceeded $21^{\circ} \mathrm{C}$ throughout July and August, with few exceptions (fig. 4). Specifically, a distinct double peak in water temperatures occurred at all temperature monitoring sites during July and August (fig. 5). Maximum daily temperatures for all sites along the main-stem Chehalis River reached their peak for the study period in mid-July, before decreasing below $21^{\circ} \mathrm{C}$ for a 3-5 day period beginning in late July. After this cooling period, maximum daily temperatures along the main stem exceeded $21^{\circ} \mathrm{C}$ for the entire month of August (fig. 5). The highest water temperature observed along the main-stem Chehalis River was 27 ${ }^{\circ} \mathrm{C}$, on July 12 at the site located at RM 85.1 (table A5).

Water temperatures in the South Fork Chehalis River subbasin were similar to temperatures along the main-stem Chehalis River (fig. 4). Maximum daily temperatures exceeded $21{ }^{\circ} \mathrm{C}$ throughout July and August, and exhibited the same3-day cooling trend observed at all other sites in late July (fig. 5). The maximum temperature observed in the South Fork Chehalis River was $26.1^{\circ} \mathrm{C}$ on August 4 , 2014 (table A6)

Throughout the study period, maximum daily temperatures in the upper Chehalis River were consistently cooler than maximum daily temperatures measured at all sites along the main stem and South Fork Chehalis River (figs. 4 and 5). The average maximum daily temperature in the upper Chehalis River subbasin exceeded $21^{\circ} \mathrm{C}$ throughout much of August, with the maximum observed temperature of $24.7^{\circ} \mathrm{C}$ on August 4, 2014. The average daily temperature in the upper Chehalis River exceeded $21^{\circ} \mathrm{C}$ on only 1 day during the study period. 


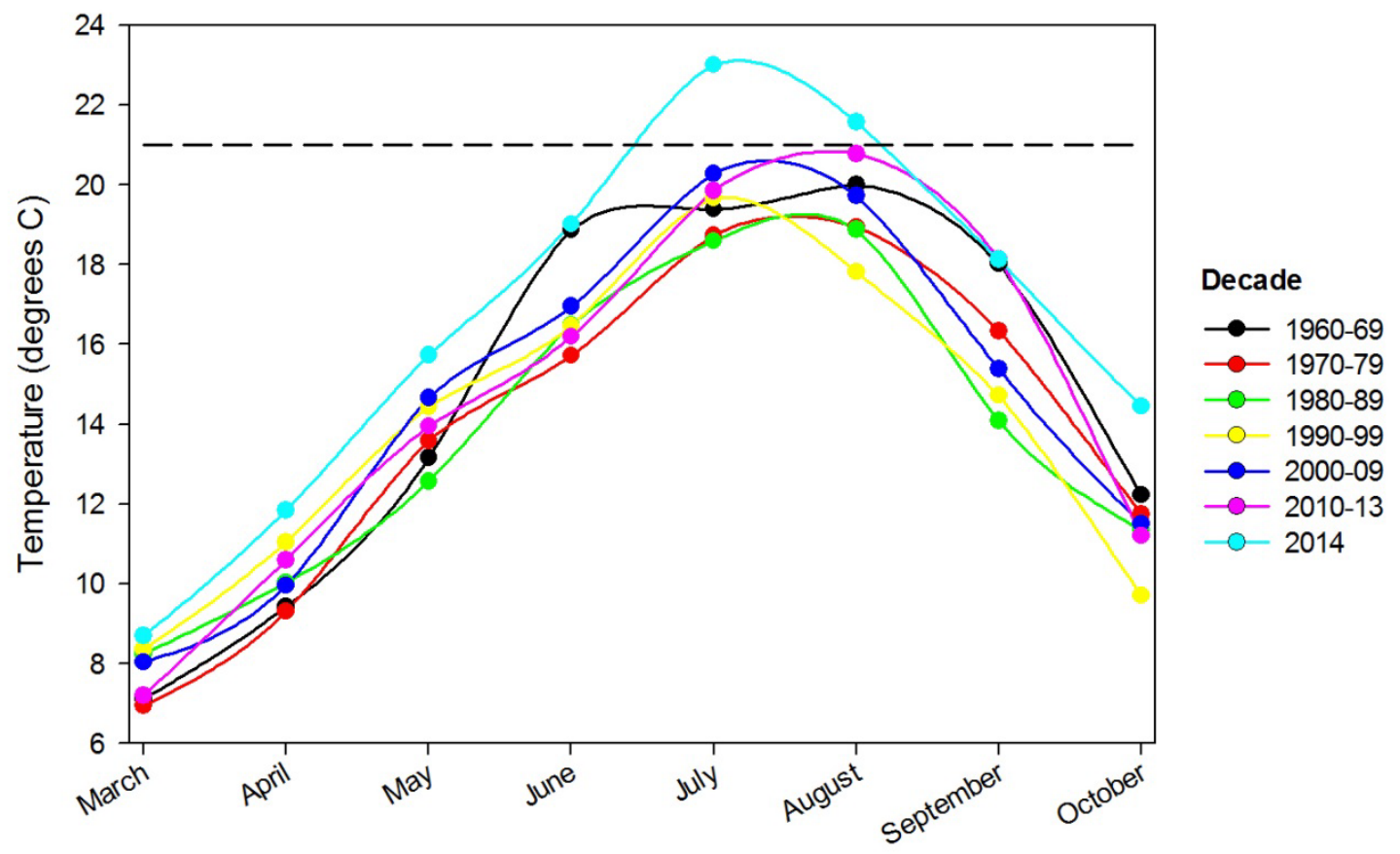

Figure 2. Graph showing water temperature on the main-stem Chehalis River, southwestern Washington, 1960 2014. Water temperatures are monthly measures obtained from Station 23A070 (Washington State Department of Ecology) near Porter, Washington. Horizontal line at 21 degrees Celsius $\left({ }^{\circ} \mathrm{C}\right)$ is added for reference. Data shown are decadal averages. Data for 2014 are shown separately.

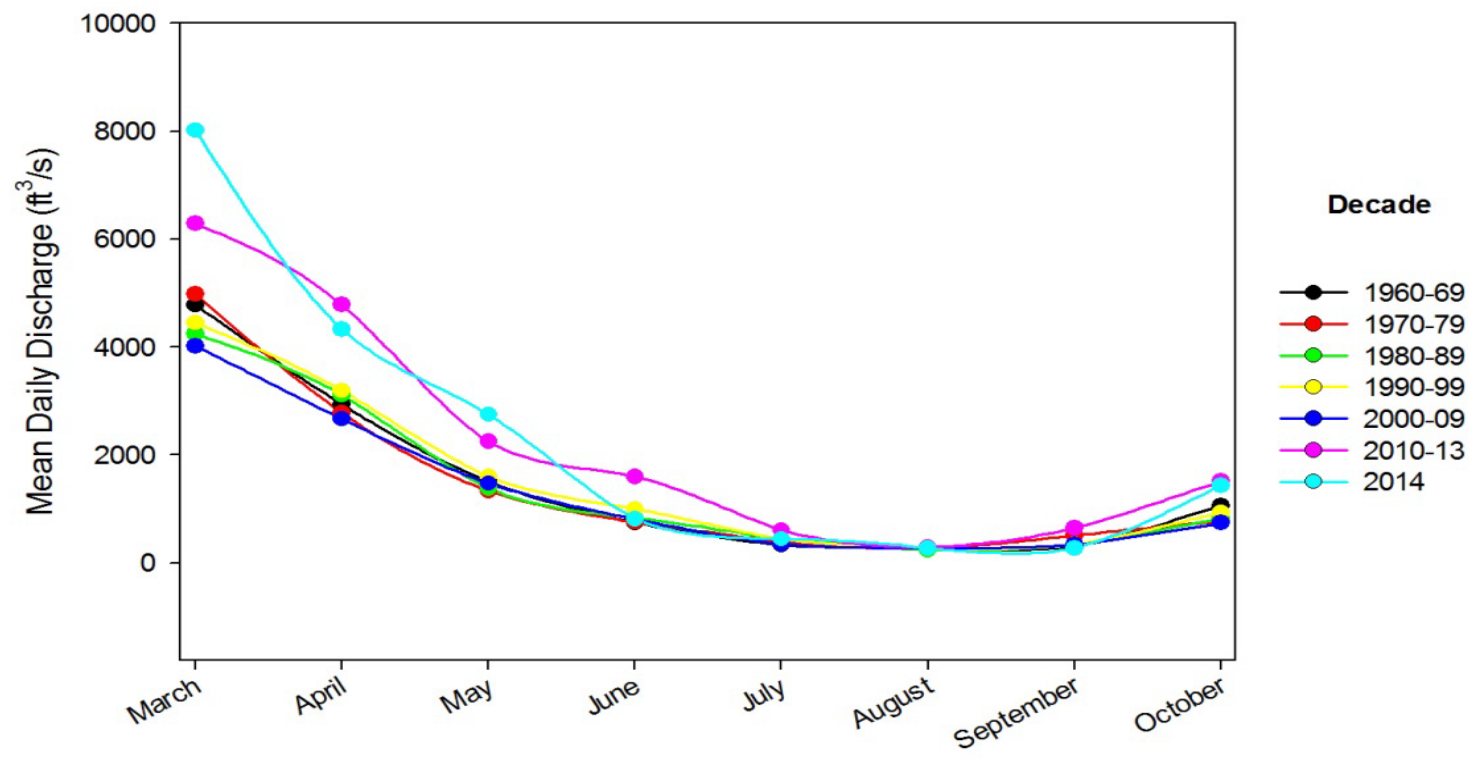

Figure 3. Graph showing monthly discharge on the main-stem Chehalis River, southwestern Washington, 19602014. Streamflows are the monthly average of mean daily discharge measurements obtained from USGS streamgage Chehalis River near Grand Mound, WA (12027500). Data shown are decadal averages. Data for 2014 are shown separately. $\mathrm{ft} 3 / \mathrm{s}$, cubic feet per second. 


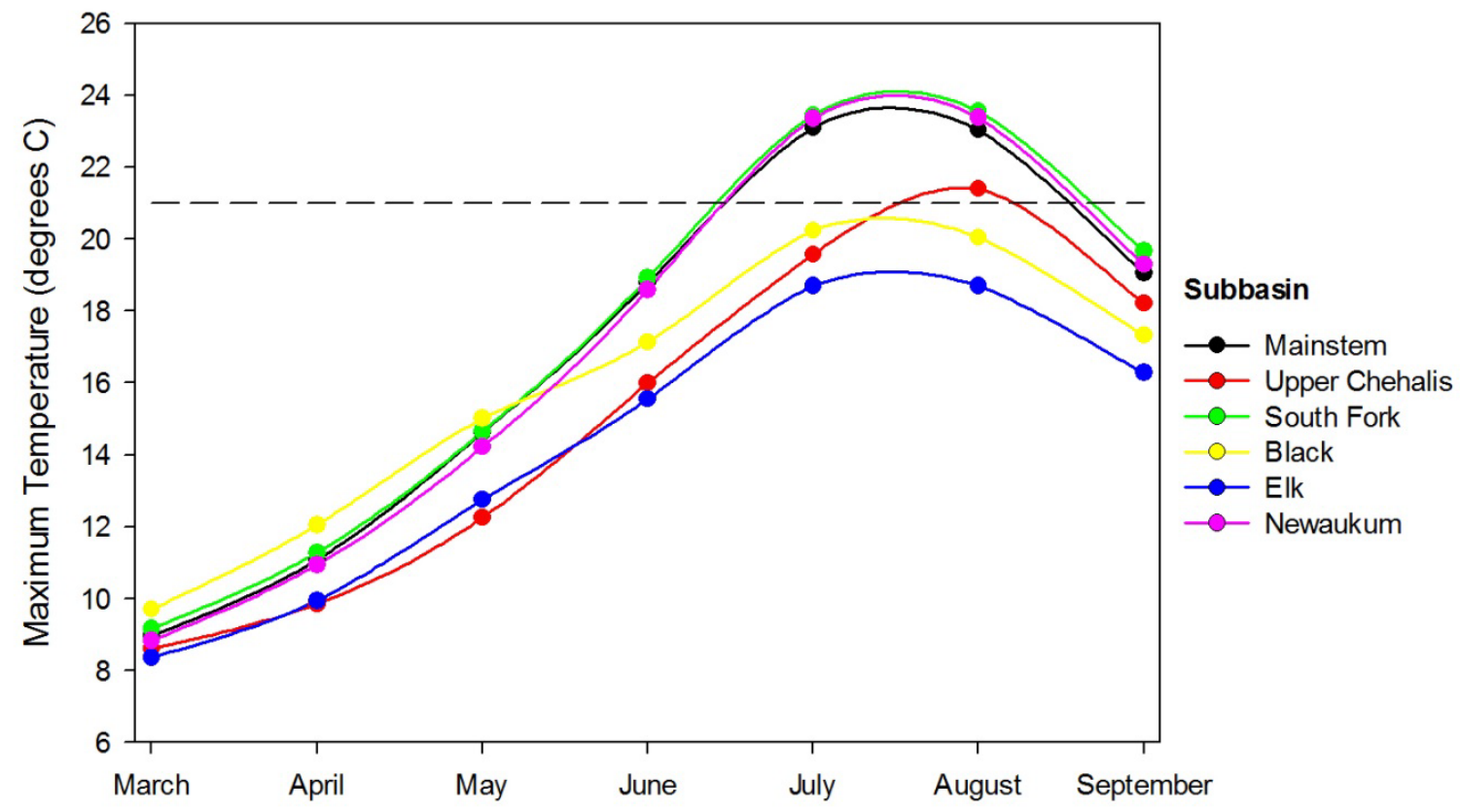

Figure 4. Graph showing maximum stream temperature by month in the subbasins of the Chehalis River Basin, southwestern Washington, March-September 2014. Data are monthly mean of maximum daily temperature values. Each subbasin is plotted separately. Horizontal line at 21 degrees Celsius $\left({ }^{\circ} \mathrm{C}\right)$ is added for reference.

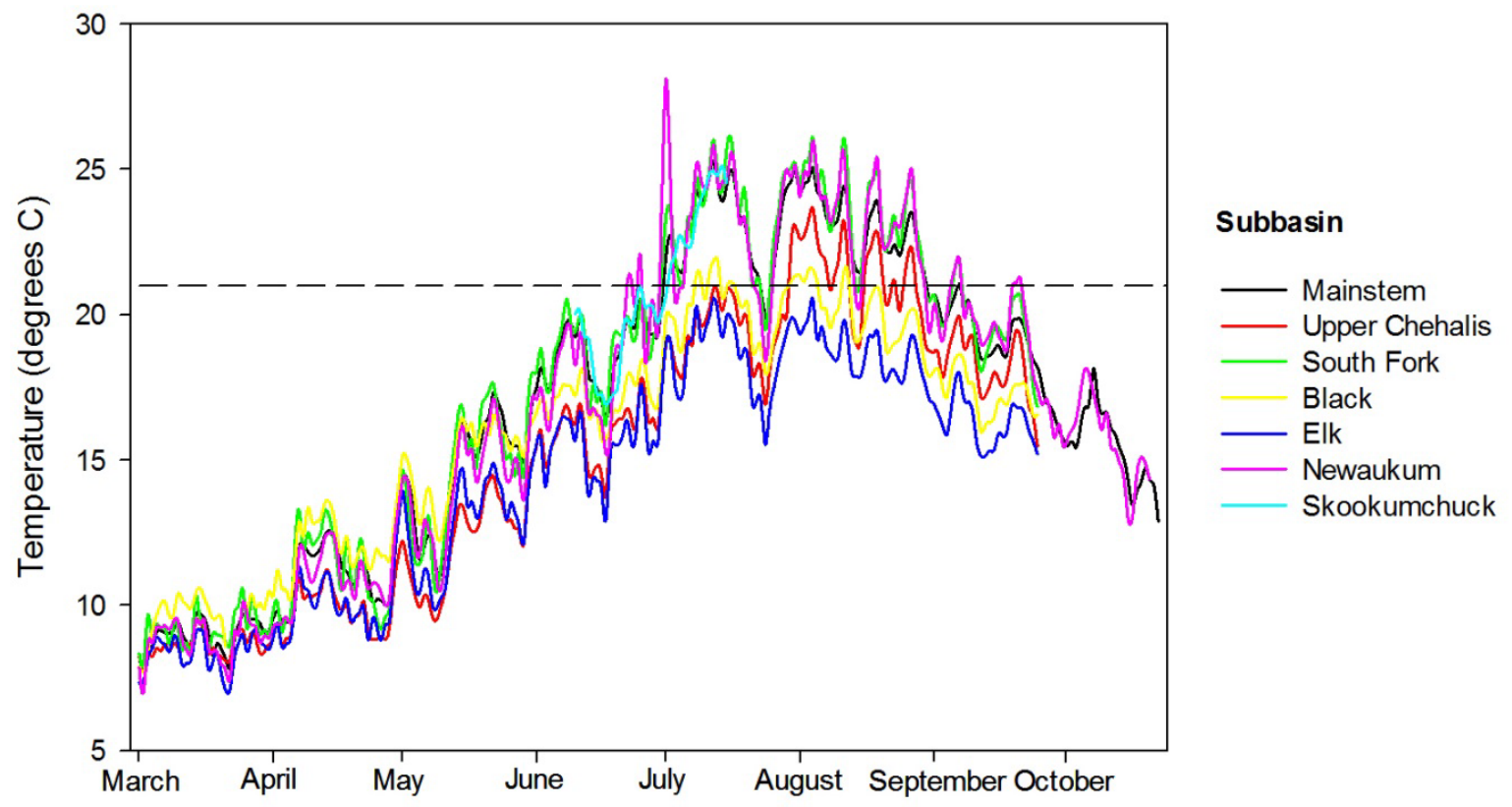

Figure 5. Daily maximum stream temperature in the subbasins of the Chehalis River Basin, southwestern Washington, March-September 2014. Data are mean of maximum daily temperature values. Each subbasin is plotted separately. Horizontal dashed line at 21 degrees Celsius $\left({ }^{\circ} \mathrm{C}\right)$ added for reference. 
Water temperatures in Elk Creek were consistently cooler than temperatures in other subbasins and never exceeded $21^{\circ} \mathrm{C}$ during the study period (fig. 4). Conversely, maximum daily water temperatures in the lower South Fork Chehalis River and the lower Newaukum River exceeded $21{ }^{\circ} \mathrm{C}$ throughout July and August and were comparable to water temperatures on the main-stem Chehalis River during the same time period (fig. 4).

Limited water temperature data were available for the Skookumchuck River subbasin during summer 2014. Vandalism of temperature loggers in the lower Skookumchuck River prevented the collection of a continuous water temperature dataset for this area despite repeated redeployments of temperature loggers. Water temperatures for the lower Skookumchuck River were limited to mid-June to mid-July 2014 (fig. 5). Based on the limited data available for analysis, maximum daily water temperature in the lower Skookumchuck River exceeded $21^{\circ} \mathrm{C}$ beginning in early July, with the maximum observed temperature of $25.1^{\circ} \mathrm{C}$ occurring on July 14, 2014.

\section{Spring Chinook Salmon Movements}

Overall, 11 of the 12 tagged fish (92 percent) were detected by either the fixed sites or during mobile tracking efforts (or both) after their release. The one fish (fish 3) that was not detected by either method was captured, tagged, and released near RM 42.1 on the Chehalis River, and was confirmed to have been captured and harvested upstream of the release location by a Tribal fishing net near the town of Oakville, Washington (RM 48) about 2 weeks after it was released (table 3). The mean number of days in the detection histories for tagged fish was 102 days, and the fish with the longest detection history was tracked for 144 days (table 3). Nine tagged fish (75 percent) had more than 111 days of detections, from the time of release to the end of the study period.

Fixed sites detected eight (67 percent) of the tagged fish released in the Chehalis River (table 3 ). None of the tagged fish were detected at or upstream of RM 91.6 (near the town of Ceres, Washington) or near the mouth of the Chehalis River at RM 6.1. The fixed site at the mouth of the Skookumchuck River detected the highest proportion of tagged fish (seven fish, 58 percent). Six tagged fish (50 percent) were detected at the fixed site near the town of Grand Mound, Washington, at RM 62.8. The fixed site at the mouth of the Newaukum River detected four tagged fish (33 percent). The site downstream of Porter, Washington, at RM 33.6 detected three tagged fish (25 percent). On average, individual tagged fish were detected by two fixed sites, and one fish was detected by four fixed sites.

Mobile tracking efforts generated 96 fish detections, primarily from the main-stem Chehalis River (82 percent), where mobile tracking efforts were concentrated. Nearly one-third (32 percent) of all detections generated by mobile tracking occurred within a $0.5 \mathrm{RM}$ reach centered on the mouth of the Skookumchuck River. Mobile tracking was conducted throughout the study area beginning in late-May through the end of October in an effort to locate tagged fish that had not been detected by the fixed sites. Regular mobile tracking efforts in the Newaukum and Skookumchuck Rivers began in late September, and continued through October 29, 2014. The mean number of mobile tracking detections per fish was 8, with a minimum of 0 detections and a maximum of 17 detections (table 3 ).

Each fish was assigned a fate based on review of the detection histories. Overall, six tagged fish (50 percent) were assigned a fate of spawner based on detections of these fish in spawning areas during the spawning period (table 3 ). Three fish ( 25 percent) showed limited movement after release and were estimated to have either died or regurgitated their transmitter (spit/mortality fate). Two tagged fish (17 percent) were assigned a fate of unknown due to gaps in their detection histories. The final fish ( 8 percent) was confirmed to have been harvested by a tribal fishing net about 2 weeks after it was tagged (table 3). 
Seven (58 percent) of the radio-tagged spring Chinook salmon moved upstream following release (table 4). Four of these seven fish moved upstream within about a week after release (5-8 days), two fish were first detected moving upstream about 5 weeks after release (34-35 days), and one fish stayed near the release location for 98 days before moving upstream (table 4). All seven tagged fish moved upstream past the fixed sites at RM 33.6 and RM 62.8 quickly, being detected at each of these two sites briefly before moving upstream to the mouths of the Skookumchuck or Newaukum Rivers (fig. 6). The longest residence time for a fish at a fixed site was for fish 8, which was continuously detected by the fixed site at the mouth of the Skookumchuck River for 17.7 days, following the installation of this site in early September. The mean residence time for fish at each fixed site ranged from 5.3 min to 10 days. The average migration rates through various reaches in the main-stem Chehalis River, based on fixed site detections, ranged from 5.1 to $17.9 \mathrm{mi} / \mathrm{d}$. The mean maximum displacement for these seven fish, calculated as total river miles from the release location to the farthest point away from the release location, was 39.8 river miles (minimum 22.3 river miles, maximum 78.5 river miles).

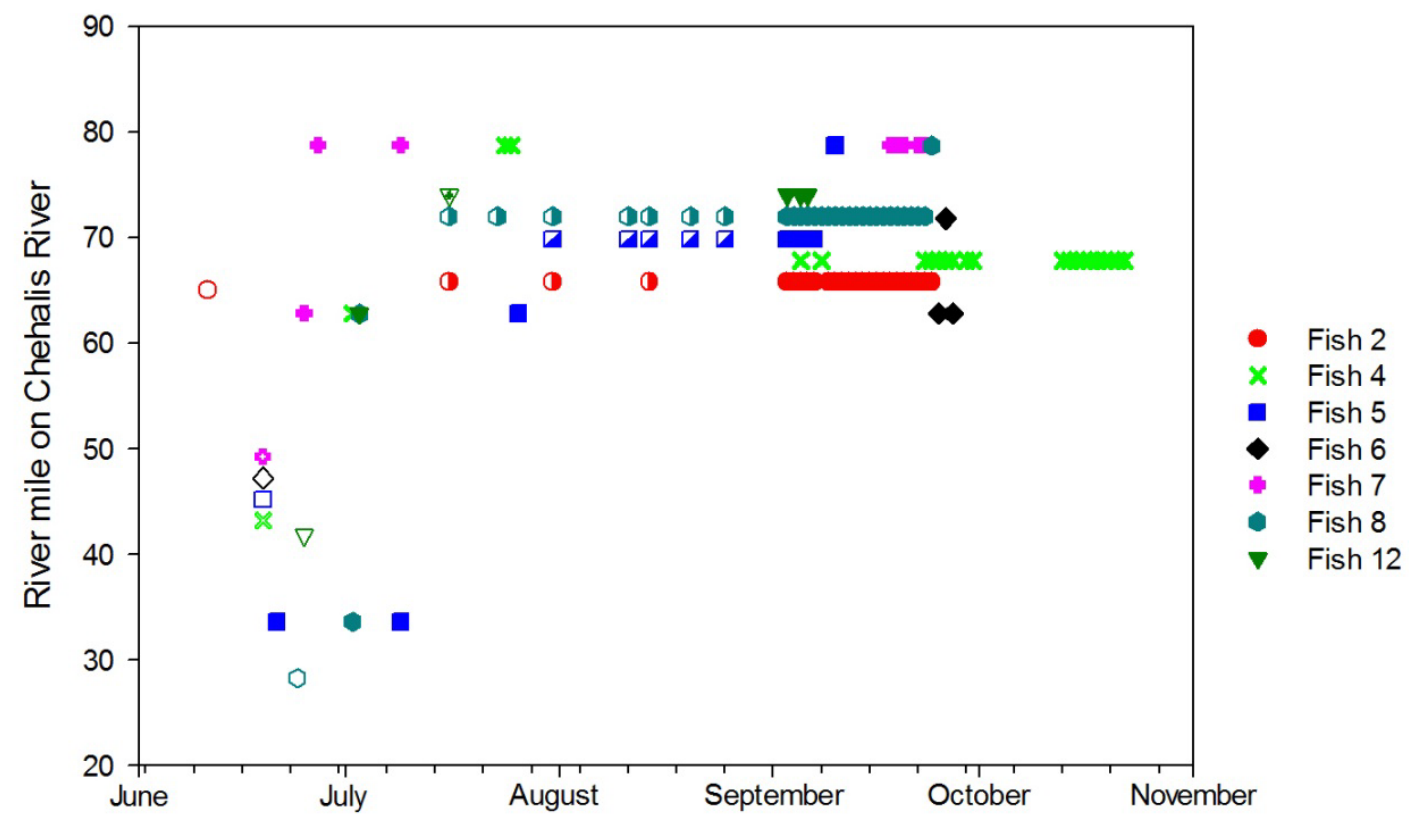

Figure 6. Graph showing timing of movements for seven radio-tagged spring Chinook salmon, Chehalis River Basin, southwestern Washington, June-October 2014. Tagged fish were detected at fixed monitoring locations along the Chehalis River (see table 1 for river mile location of fixed sites) as they moved upstream toward spawning areas. For each fish, solid filled shapes show dates and locations (by river mile) of fixed site detections, semi-filled shapes show dates and location (by river mile) for mobile detections for four fish that migrated to the mouth of the Skookumchuck River prior to the installation of the fixed site at that location, and open shapes show the location (by river mile) and date of release. Fish numbers indicated in the figure correspond to the fish numbers shown in table 3. 
The final fates for the seven fish that moved upstream following release included six fish that were assigned a fate of spawner, and one fish with an unknown fate (tables 3and 4). Fish 6, which was assigned a fate of unknown, remained near the release site for 98.2 days before moving upstream 26.6 river miles to the mouth of the Skookumchuck River in late September (table 4). Following a short residence time at this fixed site, it was detected moving downstream by the fixed site at RM 62.8. The final detection for fish 6 occurred during mobile tracking in late October near Oakville, Washington (RM 48). This fish survived until the spawning period, and was in the general vicinity of Cedar Creek (RM 41.8) when it was last detected, but the limited number of detections prevented a confident assignment as a spawner fate.

Of the six fish assigned a fate of spawner, one-half had final locations in the Skookumchuck River, and the remaining one-half had final locations in the Newaukum River. In the Skookumchuck River, two fish (fish 4, fish 12) were last detected at the mouth of the river (RM 69.8) in early September and late October, respectively. One fish (fish 2) moved upstream to RM 21.6 in the Skookumchuck River and was last detected there in late October. In the Newaukum River, fish 7 was last detected in the main-stem Newaukum River at RM 1.4 in late October. The other two fish were last detected in the South Fork Newaukum River at RM 5.4 (fish 5) and RM 17.8 (fish 8) in late October.

As a group, the six fish assigned a fate of spawner had a mean maximum displacement of 42.1 river miles from their release sites (minimum 22.3 river miles, maximum 78.5 river miles). Fish 8 demonstrated the largest maximum displacement from its release site, moving 78.5 river miles upstream to spawn in the South Fork Newaukum River.

Three ( 25 percent) of the radio-tagged Chinook salmon captured and released during this study showed very limited movement from their release sites, and were assigned a spit/mortality fate. All detections of these fish (fish 1, fish 9, and fish 10) occurred within 2.1 RM of their respective release locations. These fish were only detected during mobile tracking surveys, and were not detected by any fixed sites. The mobile detections documenting the lack of movement of these fish accounted for 41 percent of all mobile tracking detections generated during this study. 
Table 4. Timing of first date of detection on fixed-location telemetry monitoring sites (fixed sites) for radio-tagged spring Chinook salmon captured and released in the Chehalis River Basin, southwestern Washington, 2014.

[Release locations for fish are shown in rows with dark gray shading. The locations of fixed sites are shown as river miles (RMs) on the main-stem Chehalis River and are described in table 1. Details of the capture, release, and size of tagged fish are described by fish number in table 3 . The fixed site located at the mouth of the Skookumchuck River (RM 69.8) was installed on September 3, 2014, after repeated detections of tagged fish in the vicinity during weekly mobile tracking surveys. Those mobile detections are included in this table, highlighted with light gray shading]

\begin{tabular}{|c|c|c|c|c|c|c|c|c|c|c|c|c|}
\hline \multirow{2}{*}{ Detection location } & \multicolumn{12}{|c|}{ Fish number } \\
\hline & 1 & 2 & 3 & 4 & 5 & 6 & 7 & 8 & 9 & 10 & 11 & 12 \\
\hline \multicolumn{13}{|l|}{ RM 6.1} \\
\hline Release & & & & & & & & June 24 & & June 24 & & \\
\hline RM 33.6 & & & & & June 21 & & & July 2 & & & June 24 & \\
\hline Release & May 22 & & June 18 & June 19 & June 19 & June 19 & June 19 & & June 24 & & June 24 & June 25 \\
\hline RM 62.8 & & & & July 2 & July 26 & Sept. 25 & June 25 & July 3 & & & & July 3 \\
\hline Release & & June 11 & & & & & & & & & & \\
\hline Mobile 69.8 & & & & August 20 & July 31 & & & July 16 & & & & July 16 \\
\hline RM 69.8 & & Sept. 3 & & Sept. 5 & Sept. 3 & Sept. 25 & & Sept. 3 & & & & Sept. 3 \\
\hline RM 78.7 & & & & July 24 & Sept. 10 & & June 27 & Sept. 24 & & & & \\
\hline \multicolumn{13}{|l|}{ RM 91.6} \\
\hline \multicolumn{13}{|l|}{ RM 100.4} \\
\hline RM 111.0 & & & & & & & & & & & & \\
\hline
\end{tabular}


One tagged fish (fish 11) was only detected moving downstream. This fish was assigned a fate of unknown because it was released at RM 34.9, was detected moving downstream by the fixed site at RM 33.6 on the same day it was released (table 4), and was not detected again (table 3). Mobile tracking efforts in the area of the last detection did not locate the fish, and it was not detected at the furthest downstream fixed site at RM 6.1. This fish may have moved downstream past the fixed site at RM 6.1 undetected, or it may have remained in the main-stem Chehalis River between RM 6.1 and RM 33.6. The limited number of detections on this fish made a specific fate assignment difficult.

\section{Spring Chinook Salmon and Water Temperatures}

Summaries of Chinook salmon temperature exposures and ambient water temperature were based on both fixed gear and mobile tracking detections, coupled with water temperature data collected by the array of water temperature loggers deployed throughout the study area. Fixed site detections of tag temperature sensors had the potential to generate a large set of temperature exposure data, given that each tag was capable of transmitting water temperature data once every 5 seconds. However, the residence times of tagged fish at the fixed sites were relatively short throughout June and July, and none of the tagged fish were detected by fixed sites during August (table 5). Only seven individual tagged fish had tag temperature sensor data collected by fixed sites, and two of these fish had very limited detections. Tag temperature sensor data collected by the fixed sites was most abundant in September and October (table 5), after water temperatures had peaked for the year. The fixed site at the mouth of the Skookumchuck River (RM 69.8) had the most detections of temperature sensors, but they all occurred during September and October (table 5) after the site was installed in September. Every mobile tracking detection provided a tag temperature sensor reading, and there were 31 individual mobile tracking detections that were used to evaluate temperature effects. Most of these detections occurred on the main-stem Chehalis River between July and October. Repeated mobile tracking detections of several tagged fish near the mouth of the Skookumchuck River began in July, suggesting that tagged fish were holding in this location during the time period when peak water temperatures were observed at sites along the main-stem Chehalis River. As this holding location was not foreseen, the fixed site at the mouth of the Skookumchuck River was not installed until September 3, 2014, following the findings from mobile tracking efforts. The late installation of this fixed site prevented the collection of temperature records during the peak water temperatures. After installation, this fixed site detected five individual fish for extended periods throughout September and October, generating a relatively large set of temperature records at this location. 
Table 5. Mean selected water temperatures based on transmitter temperature sensor readings for radio-tagged spring Chinook salmon detected by fixed-site telemetry monitoring stations (fixed sites) in the Chehalis River, southwestern Washington, 2014.

[Transmitter temperature sensor readings (in degrees Celsius) for all tagged fish detected by a fixed site in each month were averaged and are presented by fixed site and month. Standard deviation of mean is indicated in parentheses. Locations of fixed sites are shown as river miles (RMs) on the main-stem Chehalis River and are described in table 1. NA, not applicable]

\begin{tabular}{|c|c|c|c|c|c|c|}
\hline \multirow{2}{*}{ Fixed site } & \multicolumn{6}{|c|}{ Mean water temperatures, in degrees Celsius } \\
\hline & May & June & July & August & September & October \\
\hline RM 6.1 & NA & NA & NA & NA & NA & NA \\
\hline RM 33.6 & NA & $17.7( \pm 1.1)$ & $21.9( \pm 0.3)$ & NA & NA & NA \\
\hline RM 62.8 & NA & $20.1( \pm 0.4)$ & $20.9( \pm 0.5)$ & NA & $17.8( \pm 0.4)$ & NA \\
\hline RM 69.8 & NA & NA & NA & NA & $19.0( \pm 1.0)$ & $13.7( \pm 0.8)$ \\
\hline RM 78.7 & NA & $18.6( \pm 0.5)$ & $20.7( \pm 1.1)$ & NA & $22.4( \pm 0.6)$ & NA \\
\hline RM 91.6 & NA & NA & NA & NA & NA & NA \\
\hline RM 100.4 & NA & NA & NA & NA & NA & NA \\
\hline RM 111 & NA & NA & NA & NA & NA & NA \\
\hline
\end{tabular}

\section{Movement Timing}

The timing of the movements of spring Chinook salmon in the Chehalis River appeared to be related to water temperature. Fish primarily moved upstream prior to or after water temperatures peaked during July and August. No movements between fixed sites were observed between mid-July and the beginning of September, with one exception (fish 5, fig. 6). Of the seven fish that moved upstream following release, four fish (57 percent, fish 4, fish 7, fish 8, fish 12) moved upstream prior to the maximum water temperatures in mid-July, one fish (14 percent, fish 5) moved upstream in mid-July and then stopped moving until early September, and two fish (29 percent, fish 2, fish 6) did not show any substantial movement from their release location until September (table 4, fig. 6). The four fish that moved upstream early in the summer began moving shortly after release and were detected near the mouth of the Skookumchuck River during July, August, and September. All four of these fish entered either the Skookumchuck River (two fish) or the Newaukum River (two fish) in September or early October and were assumed to have spawned. The release dates for these four early-moving fish were June 19 (two fish), June 24 (one fish), and June 25 (one fish)(table 4).

Two tagged fish (fish 2, fish 6) exhibited a late-summer movement pattern. Fish 2 was released about 1 river mile downstream of the junction with the Skookumchuck River in mid-June, but was not detected near the junction until early September (table 4). The fish then moved into the Skookumchuck River, up to RM 21.6 where it was last detected in late October and was assigned a fate of spawner (table 3). Fish 6 remained near the release site low in the system for 98 days before quickly moving upstream to the mouth of the Skookumchuck River in late September (table 4). Fish 6 then moved downstream in the Chehalis River and was last detected in late October near RM 48, and was assigned a fate of unknown (table 3). 
Fish 5 was the only fish to move between fixed sites during peak water temperatures in July and August (fig. 6). This fish moved downstream shortly after release, before beginning its upstream migration in early July, arriving at the mouth of the Skookumchuck River in late July where it held before continuing upstream and entering the Newaukum River in mid-September (table 4). It was last detected in the South Fork Newaukum River at the end of October and was assumed to have spawned (table 3).

\section{Site Selection}

Tagged fish were not frequently detected at sites where water temperatures exceeded $21^{\circ} \mathrm{C}$. Collectively, the temperature records for tagged fish at sites where temperature exceeded $21{ }^{\circ} \mathrm{C}$ represented only 0.2 percent of the total temperature sensor observations summarized, indicating that fish detected by fixed sites did not hold for extended periods in locations where temperatures exceeded $21{ }^{\circ} \mathrm{C}$ (table 5). The mean tag sensor temperature for fish detected by each fixed site for each month of the study period exceeded $21^{\circ} \mathrm{C}$ in only two instances (table 5). A finer scale examination of mean tag sensor temperatures of individual tags at each of the fixed sites revealed that four individual fish were exposed to temperatures exceeding $21^{\circ} \mathrm{C}$ at three locations. At the fixed site at RM 33.6, two fish (fish 5 , fish 8) recorded mean monthly temperatures of $21.9{ }^{\circ} \mathrm{C}$ during July. At the fixed site at RM 62.8, three fish (fish 5, fish 8, and fish 12) recorded mean monthly temperatures of 21.2, 21.3, and $21.0{ }^{\circ} \mathrm{C}$, respectively, in July. The residence times for these fish at these locations was short, from 3 to 14 minutes. At the fixed site at the mouth of the Newaukum River, fish 7 recorded mean monthly temperatures in July and September of 21.5 and $22.4^{\circ} \mathrm{C}$, respectively. In September, at the mouth of the Newaukum River, fish 7 demonstrated the longest residence times for any tagged fish in water that exceeded $21^{\circ} \mathrm{C}$, being detected for 6.5-9.3 hours on two separate dates.

Mobile tracking detections showed the same pattern as fixed site detections in that fish were not commonly at locations where water temperatures exceed $21^{\circ} \mathrm{C}$. Fish detected by mobile tracking in the South Fork Newaukum River in October (six detections, two individual fish) did not have any tag temperature sensor readings exceeding $21^{\circ} \mathrm{C}$, although water temperatures in this tributary were generally below this threshold in October. Fish 8 was located at South Fork Newaukum River RM 17.8 with a mean temperature of $15.1^{\circ} \mathrm{C}$. Fish 5 was located lower in the South Fork Newaukum River at RM 5.4 during the same time period and had a mean water temperature of $12.1{ }^{\circ} \mathrm{C}$. One fish was detected during mobile tracking in the lower main-stem Newaukum River at RM 1.8 during October (four detections) and reported a mean temperature of $23.0^{\circ} \mathrm{C}$. In the Skookumchuck River, in October, fish 2 was detected at RM 21.6 and had a mean temperature of $16.0^{\circ} \mathrm{C}$. Mean daily water temperature data were available from the fish hatchery located $0.4 \mathrm{RM}$ upstream of this detection location and were consistent with the temperature reported by the tag temperature sensor on each date of detection. 
Mobile tracking detections provided some examples of fish selecting micro-habitats where water temperature was substantially cooler than the surrounding area. Water temperature loggers were not present in the South Fork Newaukum River, so mobile tracking detections in this subbasin could not be compared to ambient water temperatures. In the main-stem Chehalis River mobile tracking efforts generated 19 detections of tagged fish. Seven of the 19 detections ( 37 percent) had tag temperature sensor readings over $21^{\circ} \mathrm{C}$, occurring in July (4 detections), August (2 detections), and September (1 detection). Five mobile detections, at RM 74.6, were paired directly with water temperature logger data collected at the same location as the mobile detection. During two of the five detections ( 40 percent), the tag temperature sensor was $1.1-2.7^{\circ} \mathrm{C}$ cooler than the ambient water temperature as measured by the water temperature logger. When accounting for the $0.8^{\circ} \mathrm{C}$ sensitivity range of the tag's sensor, the nominal temperature difference between tag temperature and ambient temperature indicated that fish were in water that was $0.3-1.9^{\circ} \mathrm{C}$ cooler than the ambient river temperature. In addition to the water temperature logger data, three of these mobile detections were paired with surface water temperature data collected by mobile tracking teams using a handheld thermometer near the position of each fish. Surface temperatures were $1.6-3.6^{\circ} \mathrm{C}$ warmer than the reported tag temperature sensor data and were also $0.5-3.7^{\circ} \mathrm{C}$ warmer than water temperature as measured by the temperature logger. These limited data suggest some amount of thermal stratification occurred at this site and that spring Chinook salmon may be selecting micro-habitats within the water column that were cooler than the surrounding area.

Fixed site detections provided additional evidence that fish selected micro-habitats where water was substantially cooler than the surrounding area. Tag temperature sensor data from all fixed site detections were paired with data from the nearest water temperature logger, and several instances were noted where the temperature reported by the temperature sensor was more than $0.8^{\circ} \mathrm{C}$ (the sensitivity of the tag's temp sensor) cooler than the nearest logger. Differences between the temperature sensor and the temperature logger that were less than $0.8^{\circ} \mathrm{C}$ were not considered (assumed to be no difference) because they were outside of the temperature sensor's sensitivity. A large proportion of the fixed site detections (42 percent) involved fish 4 and occurred at the mouth of the Skookumchuck River during September and October. Fish 4 held in this area, within range of the fixed site, for extended periods during these months, generating 52,365 total temperature sensor records. Of these temperature records, 28,109 records (54 percent) indicated that the fish was holding in water cooler than the ambient river temperature as measured by the nearest water temperature logger, located 4.8 river miles upstream (RM 74.6). In many instances, the tag sensor temperature was much cooler (up to $7^{\circ} \mathrm{C}$ ) than the temperature recorded by the nearest logger, suggesting that the fish was holding in or very near the mouth of the Skookumchuck River. Temperature logger data were not available from the lower Skookumchuck River during this time period, so a direct comparison of tag temperature to Skookumchuck River temperature was not possible. 


\section{Discussion}

\section{Preliminary Investigation 2014}

The preliminary evaluation of spring Chinook salmon movements in the Chehalis River provided valuable information for the immediate needs of resource managers as well as for the design and execution of future evaluations. Although few fish were tagged and monitored for this study, the general distribution of fish and the timing of their movements were well documented. With this new information, future evaluations can more effectively position monitoring stations and locate and capture fish for tagging. Additionally, future water temperature monitoring efforts can be more effectively designed to provide stream temperatures in locations where fish may aggregate and hold.

Water temperatures in the Chehalis River during the 2014 study period were higher than historical averages. While flows were relatively similar to historical averages along the main stem in 2014, lack of rainfall throughout the summer, coupled with above average air temperatures likely contributed to warmer stream temperatures than observed in typical years. As a result, the ambient river environment encountered by spring Chinook salmon as they entered freshwater was warmer, earlier in the season than what these fish would experience during a typical summer in the Chehalis River. Additionally, these conditions persisted longer than usual throughout the summer as fish were holding and moving to spawning locations.

Radio-tagged spring Chinook salmon did not move upstream in the Chehalis River past the junction with the Newaukum River, and were not detected very low in the system, near Aberdeen, Washington. Many fish used the Skookumchuck and Newaukum Rivers. These observations are consistent with spring Chinook salmon spawning documented in the basin (Curt Holt, Washington Department of Fish and Wildlife, oral commun., 2014). In the Chehalis River, tagged fish congregated near the mouths of the Skookumchuck and Newaukum Rivers for extended periods during peak water temperatures. The fixed site near the town of Grand Mound, Washington (RM 62.8) detected the most tagged fish, although residence times at this location were relatively short.

Spring Chinook salmon in the Chehalis River used two strategies to mitigate high summer water temperatures during 2014. The warmest summer temperatures in the Chehalis River occurred in the main-stem Chehalis River during July and August. Warm summer water temperatures pose a substantial problem for adult spring Chinook salmon that must conserve energy for migration and spawning. The first approach used by tagged fish to mitigate high water temperatures was the timing of major movements to avoid the peak water temperature periods. The second approach was the selection of locations where water temperatures were cooler than surrounding environments in the basin.

The timing of major movements (10-30 river miles) observed in tagged spring Chinook salmon in the Chehalis River was primarily bi-modal. Few large movements occurred between mid-July and early September. Following tagging and release, fish either moved quickly upstream or remained in the lower river until cooler water was available in September and October. One tagged fish showed a unique movement pattern, remaining in the lower river near its release location for 20 days before moving quickly upstream to the mouth of the Skookumchuck River during July's peak water temperatures, with no other documented movements during the heat of the summer. By reducing their activity level during the summer, fish can use their energy resources to mitigate the stress and metabolic requirements associated with elevated water temperatures and conserve energy for future energy demands like migration and reproduction. 
The second temperature mitigation strategy documented in this study was the selection of locations where cool water was available. This behavioral thermoregulation strategy occurred at two scales: a micro-habitat scale and a larger spatial scale. At the micro-habitat scale, there were several examples where tagged fish occupied sites where the tag temperature sensor indicated a water temperature lower than the ambient river temperatures measured nearby. These fish found cool water refugia and used them to mitigate the high water temperatures documented throughout the Chehalis River during the peak of the summer. Although this may be an effective strategy at discrete points in time, the availability and the seasonal stability of micro-habitats that can serve as cold water refugia in the system is unknown. Given the projected long-term increases in summer water temperatures and the importance of cool water to spring Chinook salmon, existing cold water refugia might be identified and considered for special protection. Additionally, restoration efforts could be directed to locations where such micro-habitats are present. The selection of cool water sites also occurred at a larger spatial scale in that fish selected locations where not just the micro-habitats offered refuge, but the whole reach or local area had cooler water temperatures than nearby areas. This approach to mitigating temperature was the more common strategy, as tagged fish were not frequently detected at sites where water temperatures exceeded $21^{\circ} \mathrm{C}$. Special protection and restoration efforts directed to these locations would also be beneficial to spring Chinook salmon.

Stream temperatures were monitored as part of this preliminary evaluation, but enhanced efforts, both spatially and temporally, will be needed to advance the understanding of water temperature exposures and selection by spring Chinook salmon in the Chehalis River. Several agencies were involved in stream temperature monitoring efforts, and each agency had locations and timelines established for their temperature logger deployments before the radiotelemetry study was initiated. Although coordination was conducted to maximize the temperature data that would be useful for this study, ultimately there were some data gaps that limited the ability to compare water temperatures at fish locations with ambient temperatures. Additional continuous water temperature records at locations throughout all of the sub-basins, especially along the Skookumchuck and Newaukum Rivers, could provide a better understanding of site selection by spring Chinook salmon and further insight into the potential drivers of movement timing and the availability and use of cool water refugia. Enhanced stream temperature monitoring will also be useful for a wide range of other applications related to the proposed flood control and restoration strategies in the Chehalis River Basin, and to assist with documenting and planning for climate change effects.

Study fish that were assumed to have spawned were last located in the Skookumchuck and Newaukum Rivers. The fates assigned to the 12 tagged fish included 6 fish (50 percent) classified as spawners. Three of these fish had their final detection locations in the Skookumchuck River; two fish near the river's mouth, and one fish almost 22 river miles upstream. The three remaining spawners were last detected in the Newaukum River; one fish in the lower section and two fish in the South Fork Newaukum River. As these tributaries are known spawning areas for spring Chinook salmon, these findings are not surprising. They do, however, provide some evidence that study fish were able to mitigate the stresses of collection, handling, and release, and were likely demonstrating representative behaviors during the study period. 
The collection of spring Chinook salmon for tagging was one of the most challenging aspects of this study. The goal was to collect fish as low in the system as possible so that the movement of fish upstream could be monitored. The fish were difficult to locate and collect, and even with substantial effort, including consulting with local experts, fewer fish were tagged than desired. The timing and size of the spring Chinook salmon run were difficult to evaluate in the Chehalis River, but the impression we gathered from local guides and fishermen was that the numbers of fish were lower than typical for the May to June period when we focused our collection efforts. We did not attempt angling in July in order to avoid the stresses of capture and handling of fish during elevated water temperature conditions. Because fish were difficult to collect, the ability to screen study fish for condition prior to tagging was very limited and may have contributed to the 25 percent of study fish assigned a spit/mortality fate. Although the goal was to restrict tagging to fish in very good condition following capture, the need to equip at least some fish with tags, combined with the joint-agency approach to fish collection and tagging may have compromised this ideal. Study fish that were negatively affected during capture, for example by a long fight period or an injury from a hook, were more likely to die or regurgitate their transmitter. In a preliminary investigation such as this, the reduced sample size and potential behavioral bias that result from this outcome can be managed. Future evaluations should, however, establish and use screening criteria for study fish to ensure that inferences made from study fish are representative of spring Chinook salmon in the basin.

The combined monitoring approach used during this study added significantly to the understanding of spring Chinook salmon movements in the Chehalis River. The array of fixed sites allowed us to monitor the large-scale movements of tagged fish and to monitor fish temperature selection continuously while fish were within range of a fixed site. The mobile tracking efforts allowed fish to be positioned on a finer scale between the fixed site locations, and in areas outside of the array, like the Newaukum and Skookumchuck Rivers. Continuing mobile tracking efforts into the spawning season was very helpful in describing the final locations for tagged fish and assisted with fate assignments. The combination of the two monitoring approaches allowed us to generate detailed detection histories for the majority of tagged fish. For future studies where fish temperature selection is monitored we would recommend adding additional fixed sites in locations where fish are likely to aggregate and hold, with stream temperature monitoring near each site. Although fixed sites for this study were selected based on anticipated holding areas, very limited information was available on spring Chinook salmon movements in the basin. Although the array of fixed sites effectively detected substantial movements of study fish, very few fish had extended residence times within range of the sites. The site at the mouth of the Skookumchuck River was an exception, and was installed late in the season, using an adaptive approach to expand the monitoring capabilities of the fixed site array. To address questions related to fish temperature selection, the most powerful dataset for analyses will be generated when fish spend several days within range of a fixed site that is in close proximity to one or more continuously operating stream temperature loggers. The long record of sensor data will allow validation of the sensor data against known stream temperatures and to eliminate records with low signal strength or radio frequency interference that can produce high variability in sensor data (Liedtke and others, 2016). Mobile tracking data are very useful for positioning fish, but are less so for evaluating temperature selection because they are typically point samples or very short (minutes) time series. Using the two techniques together for monitoring tagged fish was a powerful approach. 
This preliminary evaluation described the movements and behavior of adult spring Chinook salmon from their entry into freshwater through their spawning period in 2014, and represents a substantial contribution to our understanding of these fish in the Chehalis River Basin. The stream temperatures during our study period were not typical of the historical conditions in the system, and the numbers of tagged fish monitored was low, so results should be interpreted with those caveats in mind.

This pilot effort was successful in that the information collected on fish movements provides valuable information for the immediate needs of resource managers as well as for the design and execution of future evaluations. A follow-on investigation of spring Chinook salmon movements and thermal exposures in the Chehalis River Basin was conducted in 2015 (Liedtke and others, 2016) using the findings of the preliminary investigation to inform study design and execution.

\section{Integrated Perspectives from the 2014 and 2015 Evaluations}

Following the preliminary investigation conducted in 2014, the continuing and expanding interest in spring Chinook salmon in the Chehalis River Basin fostered a subsequent radiotelemetry evaluation in 2015. The 2015 evaluation followed a similar approach as the 2014 study, using a transmitter with a temperature sensor, a combination of fixed site monitoring stations and mobile tracking to monitor fish movements, and a greatly expanded array of stream temperature loggers (Liedtke and others, 2016). In an effort to improve the ability to compare transmitter temperature sensor data to ambient river temperatures, temperature loggers were co-located with fixed site monitoring stations in 2015. Additionally, bathythermograph surveys were conducted monthly at the mouths of the Skookumchuck and Newaukum Rivers to describe water temperatures and water depths at these important tributary junctions (Liedtke and others, 2016). Liedtke and others (2016) provides a detailed summary of the 2015 study findings, and this section of the report is intended to integrate the 2014 and 2015 study findings.

The 2015 spring Chinook salmon evaluation in the Chehalis River released 23 radio-tagged fish between April and July, and followed their movements in the main-stem Chehalis River and in the Newaukum River (Liedtke and others, 2016). About one-half (11 fish) of the tagged fish were captured and released in the main-stem Chehalis River, and the remainder (12 fish) were captured and released in the South Fork Newaukum River. All fish released in the South Fork Newaukum River remained in the South Fork Newaukum River throughout the study period, and were assigned fates of spawner (5/12), pre-spawn mortality (5/12), and spit/mortality (2/12). The 11 fish released into the main-stem Chehalis River were never detected in the Chehalis River upstream of the junction with the Newaukum River and were assigned fates of spawner (3/11), pre-spawn mortality (3/11), spit/mortality (2/11), and unknown $(3 / 11)$. The three fish assigned a fate of spawner were last detected at the mouth of the Skookumchuck River (one fish), in the Newaukum River (one fish), and in the North Fork Newaukum River (one fish) during the spawning period (Liedtke and others, 2016). 
The collection of spring Chinook salmon for tagging was a substantial challenge during both years of study. Fish were not heavily concentrated in the main-stem Chehalis River from April to June when collection efforts were concentrated. The research teams consulted with local fishermen, Tribal fishermen, and local guides to identify potential collection areas, and used a variety of capture methods (angling and tangle nets) with limited success. Fewer fish were tagged than desired in both study years, despite a large effort dedicated to fish collection. In 2015, new collection approaches and locations were used, which led to the release of tagged fish in the South Fork Newaukum River (Liedtke and others, 2016). Although these fish were collected after they had completed most of their migration and therefore did not inform movements and timing in the main-stem Chehalis River, they provided valuable insights in a system where little information is known concerning the movements of spring Chinook salmon.

The main tributaries used by tagged fish during both study years were the Newaukum and Skookumchuck Rivers, consistent with the known spawning distribution for spring Chinook salmon in the Chehalis River Basin (Washington Department of Fish and Wildlife, 2016). Tagged fish released in the main-stem Chehalis River were last detected in the Newaukum River in both 2014 and 2015, and accounted for over half of the fish assigned a spawner fate in each year. In 2014, final fish locations were in the lower Newaukum River and the South Fork Newaukum River. In 2015, final fish locations were in the Newaukum River and in the North Fork Newaukum River. The Skookumchuck River was the final location for half of the tagged fish with a spawner fate in 2014, including one fish that was last detected 22 river miles into the tributary. In 2015, one fish was last detected at the mouth of the Skookumchuck River, but no fish were documented to enter the tributary. This was a surprising finding for several reasons. First, the array of fixed sites was more extensive in 2015 and included a station at the mouth of the Skookumchuck River that operated throughout the season (unlike in 2014 when it was installed late in the season), as well as a station within the tributary that allowed confirmation of tributary entry. This enhanced monitoring in 2015 ensured reliable detection of tagged fish in and near the Skookumchuck River. Another reason that limited use of the Skookumchuck River in 2015 was surprising was that the physical access to the tributary was documented to have sufficient water depth to be accessible to fish throughout the study period (Liedke and others, 2016). Under some low-flow conditions, the junctions of the Skookumchuck River and the Newaukum River with the Chehalis River can become very shallow, restricting or eliminating physical access to these tributaries. Water depth and water temperatures were monitored monthly at both tributary junctions in 2015 to understand this potential limitation to fish movement. Finally, the lack of use of the Skookumchuck River in 2015 was surprising because this tributary has the largest spawning populations of spring Chinook salmon in the Chehalis River Basin. We expected some of the tagged fish to enter the subbasin and spawn. The low numbers of tagged fish in either study year does not fully explain these findings because there were approximately equal numbers of fish tagged in the main-stem Chehalis River in both years, but none of the 2015 fish entered the Skookumchuck River. Apart from the Newaukum and Skookumchuck Rivers, tagged fish also congregated near the mouth of Cedar Creek (RM 41.1). In 2015 the fixed site at Cedar Creek had the highest number of detections of any fixed site, and more than one third of the fish released in the main-stem Chehalis River were last detected in the area. In 2014 a fixed site was not installed near Cedar Creek, but one fish assigned a fate of unknown was last detected in the area. 
Although this fish could not confidently be assigned a fate of spawner based on the detection history in 2014, this fate seems reasonable when reviewed in light of the 2015 findings, and the documented use of Cedar Creek as a holding area. No other tagged fish spent significant time near Cedar Creek in 2014, but detection capability was limited to mobile tracking because there was not a fixed site in the vicinity.

The temperature mitigation strategies documented for spring Chinook salmon in the Chehalis

River were consistent in both study years. Large-scale movements between fixed sites were timed to avoid the peak summer water temperatures, and fish found cooler water temperatures than local conditions on both micro-habitat and larger spatial scales. Although 2014 and 2015 were atypically warm years relative to the historical averages in the basin, tagged fish were not commonly found in water temperatures exceeding $21^{\circ} \mathrm{C}$. The limited water temperature data available in 2014 made it difficult to compare the tag sensor temperature at a fish's location to a proximate temperature logger. In 2015 the water temperature monitoring array was extensive and provided valuable data for these comparisons. In both years, however, tagged fish had short residence times at the fixed sites, so there were very few examples of large temperature sensor datasets that could potentially be generated when fish spend long periods of time near a fixed site. The most powerful datasets to analyze fish temperature selection would be generated by having a spatially and temporally large array of temperature loggers to monitor ambient conditions (like what was present in 2015) and tagged fish with long-term (days or weeks) residence at fixed sites in close proximity to temperature loggers. These conditions were not fully met in either study year. We may not yet have a clear picture of spring Chinook salmon water temperature exposures and site selection in the Chehalis River, but much has been learned compared to our understanding before these studies were conducted.

Our understanding of spring Chinook salmon in the Chehalis River does not fully explain the relationship between the 2014 and 2015 study findings and the 2009 fish kill in the Chehalis River. In late July and early August 2009, approximately 100 adult spring Chinook salmon were found dead at several locations in the river, including river mile 74 and 104 of the main-stem Chehalis River and in the lower Newaukum River below the confluence of the north and south forks (Mike Kohn, Lewis County Public Utility District, written commun., 2009). Surface-water temperatures obtained from the fish kill locations by Lewis County Public Utility District on August 3 and 4, 2009 (several days after the fish kill event), exceeded $21.0^{\circ} \mathrm{C}$. Water temperature data for 2009 from long-term monitoring stations in the basin suggest that temperatures were elevated in late-July and early August, but lower than the temperatures for the same period in 2014 and 2015. Water temperatures were atypically warm during the summers of 2014 and 2015, and they posed a substantial threat to spring Chinook salmon because they were elevated early in the spring and remained elevated throughout the summer. In 2014 water temperatures exceeded $21^{\circ} \mathrm{C}$ for about 6 consecutive weeks from mid-June to early August. In 2015 water temperatures exceeded $21^{\circ} \mathrm{C}$ for about 8 weeks, from early June to early August. Despite these extensive periods of warm water temperatures, there was no evidence of spring Chinook salmon fish kills during 2014 or 2015 . Our ability to detect dead fish was strong because mobile tracking crews monitored fish holding areas regularly, especially in 2015 when mobile tracking was a large component of the monitoring effort. Additionally, in 2015 extra field crews were deployed during peak water temperatures to look for any potential dead fish, and these crews regularly looked for carcasses at sites where dead fish were reported in 2009. Compared to 2009, water temperatures in 2014 and 2015 were higher, for longer periods, but no fish kills were observed. The drivers of the 2009 fish kill are not clear as the basin was not intensively monitored at the time, but high air temperatures likely played a role. The daily maximum air temperature in Chehalis, Washington, was over $32.2^{\circ} \mathrm{C}\left(90.0^{\circ} \mathrm{F}\right)$ on 10 dates in late July and early August and reached a maximum of $42.2^{\circ} \mathrm{C}\left(108.0^{\circ} \mathrm{F}\right)$ on July 29,2009 (Mike Kohn, Lewis County Public Utility District, written commun., 2009). On July 30, 2009, dead spring Chinook 
salmon were observed on the Chehalis River (Mike Kohn, Lewis County Public Utility District, written commun., 2009). Although water temperatures obtained from the fish kill locations, several days after the first fish kill event, exceeded $21^{\circ} \mathrm{C}$, little is known about the water temperatures prior to the fish kill, the dissolved oxygen levels, or the exposure histories of the fish. Additionally, the rate and extent to which increased air temperatures drive increased water temperatures is variable and dependent on local conditions such as water depth and shading. The 2014 and 2015 evaluations showed that fish generally avoid large movements during the peak water temperatures of summer. Perhaps, in 2009, the water temperatures increased quickly, and fish did not move to cooler water or were not able to find cooler water before they were killed. Although much has been learned about how spring Chinook salmon respond to warm water temperatures in the Chehalis River, our incomplete understanding of the factors contributing to the 2009 fish kill leave spring Chinook salmon vulnerable to potential future fish kills.

Pre-spawn mortality was a commonly assigned fate for fish in the 2015 evaluation, but less so in 2014. This fate was assigned to fish if there was evidence that the fish and (or) the tag had been actively removed from the river during the study period, either through a predation or a harvest event. In 2014 one of the tagged fish (1/12, 8 percent) was confirmed to have been harvested approximately 2 weeks after it was tagged and released, and was assigned a fate of pre-spawn mortality. In 2015, however, this fate was assigned to 27 percent (3/11) of the fish released in the Chehalis River, and 42 percent (5/12) of the fish released in the South Fork Newaukum River. In the Newaukum River tagged fish were holding in a limited number of reaches, and the generally shallow nature of this river may have increased the vulnerability of these fish to capture. In the Chehalis River, the last detection location for fish assigned a fate of pre-spawn mortality was most commonly at Cedar Creek, where recreational fishing is common. In 2014, tagged fish were not commonly detected at Cedar Creek, and none of the tagged fish were released in the South Fork Newaukum River. These differences may explain the variable rates of prespawn mortality between the 2 years of radiotelemetry studies.

The fish distributions observed in the 2014 and 2015 evaluations show some incongruences compared to the documented distribution of spring Chinook salmon in the Chehalis River Basin. For example, the largest spawning populations of spring Chinook salmon occur in the Skookumchuck River, but few radio-tagged fish were detected in this subbasin. Our study fish were never detected in the Chehalis River upstream of the junction with the Newaukum River, even though a small proportion of spring Chinook salmon are known to spawn at locations higher in the system. A final example is the presence of spring Chinook salmon in the Newaukum River in late April and early May in both 2014 and 2015, when fish collection efforts were just getting started in the main-stem Chehalis River (Curt Holt, Washington Department of Fish and Wildlife, oral commun., 2016). The timing of these observations in the Newaukum River indicates that these fish entered the Chehalis River and were moving upstream to the Newaukum River early in April or prior to April. These differences in distribution and timing raise concerns that the 2014 and 2015 evaluations may not have adequately represented the entry timing and subsequent distribution of spring Chinook salmon in the Chehalis River. A study of fish behavior will have the most defensible inference to the populations of interest when it includes fish that represent the early part of the historical run, the middle part of the run, and the late part of the run because these groups will likely experience different environmental conditions and (or) their behaviors may differ based on residual energy reserves and physical condition. Studies with low sample sizes, like the 2014 and 2015 evaluations, can overcome some limitations of low statistical rigor by allocating samples to effectively represent run timing. The timing of the spring Chinook salmon run in the Chehalis River is not well documented, so it is difficult to evaluate the 2014 and 2015 studies in that context. The mismatch between the expected distribution of spring Chinook salmon and the 
observed distribution, specifically the observation of fish in the Newaukum River prior to any fish collection efforts for 2014 and 2015, suggests that the early part of the run may not have been represented, or fully represented in these evaluations. The difficulty of capturing fish also suggests that the peak of the run was not well represented or well defined, that the population numbers were low, or that the fishing locations and methods used to collect study fish were not optimal.

The 2014 preliminary investigation and the 2015 investigation of spring Chinook salmon behavior and movements in the Chehalis River made substantial contributions to the understanding of these fish in the basin. The Chehalis River Basin is currently (2016) receiving substantial research effort based on interest in proposed flood control and restoration strategies, and the need to understand the current status and ecology of aquatic species in the basin (Aquatic Species Enhancement Plan Technical Committee, 2014). For spring Chinook salmon, the key issues have been predicting responses to the proposed flood control and restoration strategies and anticipating climate change impacts. With so little information available on spring Chinook salmon movements in the basin, the findings from these radiotelemetry evaluations will be used heavily to address these needs. As both study years had warmer water temperatures than historical averages, caution should be used when making inferences to years when water temperatures are more typical. Caution is also advised when interpreting study findings, because the sample sizes overall were low, and there may be some potential bias relative to the run timing. As flood control and restoration strategies are refined and implemented, resource managers might consider working to identify locations in the Chehalis River Basin where cool water refugia such as springs or seeps might be consistently available to spring Chinook salmon and target these areas for special protection or restoration. With anticipated climate change impacts and proposed flood control measures, spring Chinook salmon will continue to be influenced by warm summer water temperatures in the Chehalis River Basin and throughout their distribution.

\section{Acknowledgments}

The authors gratefully acknowledge Curt Holt with the Washington Department of Fish and Wildlife, Mark White and Mike Mizell with the Chehalis Tribe Department of Natural Resources, and Mike Kohn with the Lewis County Public Utility District for their contributions to the approach, study design, and funding. Brett Ferris (Ferris Northwest Guide Service), Nic Norbeck (Nic Norbeck Elite Guide Service), Chris White (Washington Department of Fish and Wildlife), and John Serl (Washington Department of Fish and Wildlife) were invaluable in finding and catching fish for tagging. Ian Jezorek, Brady Allen, and Ted Jones (USGS) were also of great assistance in attempting to locate and capture fish. Brian Ekstrom and Andrew Wells with the USGS made significant contributions to the field activities and data summaries. 


\section{References Cited}

Alabaster, J.S., 1988, The dissolved oxygen requirements of upstream migrant Chinook salmon, Oncorhynchus tshawytscha, in the lower Willamette River, Oregon: Journal of Fish Biology, v. 32, p. 635-636.

Aquatic Species Enhancement Plan (ASRP) Technical Committee, 2014, Aquatic species enhancement plan: Prepared for the Chehalis Basin Work Group, August 2014, 154 p.

Berman, C.H., 1990, Effect of elevated holding temperatures on adult spring Chinook salmon reproductive success: University of Washington, Seattle, Washington, Master's thesis, 102 p.

Berman, C.H., and Quinn, T.P., 1991, Behavioural thermoregulation and homing by spring Chinook salmon, Oncorhynchus tshawytscha (Walbaum), in the Yakima River: Journal of Fish Biology, v. 39, p. 301-312.

Caissie, D., 2006, The thermal regime of rivers-A review: Freshwater Biology, v. 51, no. 8, p. 13891406.

Dauble, D.D., and Mueller, R.P., 1993, Factors affecting the survival of upstream migrant adult salmonoids in the Columbia River basin-Recovery issues for threatened and endangered Snake River salmon: Final Report to the U.S. Department of Energy, Bonneville Power Administration, Division of Fish and Wildlife, Portland, Oregon, Project number 988-026.

Dugdale, S.J., Bergeron, N.E., and St-Hilaire, A., 2015, Spatial distribution of thermal refuges analyzed in relation to riverscape hydromorphology using airborne thermal infrared imagery: Remote Sensing of Environment, v. 160, p. 43-55.

Ebersole, J.L., Liss, W.J., and Frissell, C.A., 2003, Thermal heterogeneity, stream channel morphology, and salmonid abundance in northeastern Oregon streams: Canadian Journal of Fisheries and Aquatic Sciences, v. 60, p. 1,266-1,280.

Fresh, K.L., Schroder, S.L., and Carr, M.I., 2003, Predation by northern pikeminnow on hatchery and wild coho salmon smolts in the Chehalis River, Washington: North American Journal of Fisheries Management, v. 23, p. 1257-1264.

Goniea, T.M., Keefer, M.L., Bjornn, T.C., Peery, C.A., Bennett, D.H., and Stuehrenberg, L.C., 2006 , Behavioral thermoregulation and slowed migration by adult fall Chinook salmon in response to high Columbia River water temperatures: Transactions of the American Fisheries Society, v. 135, p. 408419.

Healey, M.C., 1991, Life history of Chinook salmon (Onchorhynchus tshawytscha), in Groot, C., and Margolis, L., eds., Pacific salmon life histories: Vancouver, UBC Press, p. 312-393.

Hearsey, J.W., and Kinziger, A.P., 2015, Diversity in sympatric chinook salmon runs-Timing, relative fat content and maturation: Environmental Biology of Fishes, v. 98, p. 413-423.

Henning, J.A., Gresswell, R.E., and Fleming, I.A., 2007, Use of seasonal freshwater wetlands by fishes in a temperate river floodplain: Journal of Fish Biology, v. 71, p. 476-492.

Henning, J.A., and Schirato, G., 2006, Amphibian use of Chehalis River floodplain wetlands: Northwestern Naturalist, v. 87, p. 209-214.

Hiss, J.M., and Knudsen, E.E., 1993, Chehalis River basin fishery resources - Status, trends, and restoration: Final report by the U.S. Fish and Wildlife Service, 37 p., accessed January 8, 2016, at http://www.fws.gov/wafwo/fisheries/Publications/FP069exsum_ch1-2.pdf.

Keefer, M.L., Peery, C.A., Ringe, R.R., and Bjornn, T.C., 2004, Regurgitation rates of intragastric radio transmitters by adult Chinook salmon and steelhead during upstream migration in the Columbia and Snake Rivers: North American Journal of Fisheries Management, v. 24, p. 47-54. 
Kelsh, S.W., and Shields, B., 1996, Care and handling of sampled organisms, in Murphy, B.R., and Willis, D.W., eds., Fisheries Techniques, $2^{\text {nd }}$ edition: Bethesda, Maryland, American Fisheries Society.

Kuehne, L.M., and Olden, J.D., 2016, Environmental drivers of occupancy and detection of Olympic Mudminnow: Transactions of the American Fisheries Society, v. 145, no. 1, p. 17-26.

Liedtke, T.L., Zimmerman, M.S., Tomka, R.G., Holt, Curt, and Jennings, Lyle, 2016, Behavior and movements of adult spring Chinook salmon (Oncorhynchus tshawytscha) in the Chehalis River Basin, southwestern Washington, 2015: U.S. Geological Survey Open-File Report 2016-1158, 57 p., http://dx.doi.org/10.3133/ofr20161158.

Moser, M.L., Olson, A.F., and Quinn, T.P., 1991, Riverine and estuarine migratory behavior of coho salmon (Oncorhynchus kisutch) smolts: Canadian Journal of Fisheries and Aquatic Sciences, v. 48, p. 1670-1678.

Quinn, T.P, 2011, The behavior and ecology of Pacific salmon and trout: UBC press, Vancouver, American Fisheries Society, 320 p.

Quinn, T.P., McGinnity, P., and Reed, T.E., 2015, The paradox of 'premature migration' by adult anadromous salmonid fishes: Patterns and hypotheses: Canadian Journal of Fisheries and Aquatic Sciences, doi: 10.1139/cjfas-2015-0345.

Rahel, F.J., and Hubert, W.A., 1991, Fish assemblages and habitat gradients in a Rocky Mountain-Great Plains stream-Biotic zonation and additive patterns of community change: Transactions of the American Fisheries Society, v. 120, p. 319-332.

Richter, A., and Kolmes, S.A., 2005, Maximum temperature limits for Chinook, coho, and chum salmon and steelhead trout in the Pacific Northwest: Reviews in Fisheries Science, v. 13, p. 23-49.

Rieman, B.E., and McIntyre, J.D., 1995, Occurrence of bull trout in naturally fragmented habitat patches of varied size: Transactions of the American Fisheries Society, v. 124, p. 285-296.

Smith, C.E., Dwyer, W.P., and Piper, R.G, 1983, Effect of water temperature on egg quality of cutthroat trout: The Progressive Fish Culturist, v. 43, p. 176-178.

Smith, C.J., and Wenger, M., 2001, Salmon and steelhead habitat limiting factors - Chehalis basin and nearby drainages water resource inventory areas 22 and 23: Final report by the Washington State Conservation Commission, 448 p., accessed January 8, 2016, at http://www.ecy.wa.gov/programs/wq/tmdl/ChehalisBasin/SalmonHabLimitFactors.pdf.

Sullivan, K.D., Martin, D.J., Carwell, R.D., Toll, J.E., and Duke, S., 2000, An analysis of the effects of temperature on salmonids of the Pacific Northwest with implications for selecting temperature criteria: Final report by Suitable Ecosystems Institute, Portland, Oregon, 192 p.

Tiffan, K.F., Kock, T.J., Connor, W.P., Steinhorst, R.K., and Rondorf, D.W., 2009, Behavioural thermoregulation by subyearling fall (autumn) Chinook salmon Oncorhynchus twsawytscha in a reservoir: Journal of Fish Biology, v. 74, p. 1562-1579.

Torgersen, C.E., Price, D.M., Li, H.W., and McIntosh, B.A., 1999, Multiscale thermal refugia and stream habitat associations of Chinook salmon in northeastern Oregon: Ecological Applications, v. 9, p. 301-319.

Washington Department of Fish and Wildlife, 2016, SalmonScape database: Washington Department of Fish and Wildlife interactive mapping application, accessed October 15, 2016, at http://apps.wdfw.wa.gov/salmonscape/map.html. 


\section{Appendix A. Water Temperatures in the Chehalis River, Southwestern Washington, Summer 2014}

Table A1. Mean monthly water temperatures in the main-stem Chehalis River, southwestern Washington, summer 2014.

[Data are organized from downstream to upstream position. Location of each Site ID is shown in figure 1. NA indicates no data were available either because logger was not installed, stolen, or data did not pass the initial data screening process.]

\begin{tabular}{lcccccccc}
\hline \multicolumn{1}{c}{ Site ID } & River mile & March & April & May & June & July & August & September \\
\hline CHL-OAK & 45.2 & 8.9 & 10.9 & 14.3 & 17.8 & 21.3 & 21.4 & NA \\
CHL-US-BLK & 56.8 & 8.8 & 10.8 & 14.1 & 17.6 & 21.1 & 21.1 & NA \\
CHL-GLV_TB & 67.1 & 8.4 & 10.3 & 13.7 & 17.4 & NA & NA & NA \\
SCHEUBER & 74.6 & NA & NA & NA & 17.9 & 22.3 & 22.6 & 18.6 \\
CHL-US-NWK & 79.0 & 8.4 & 10.2 & 13.6 & 18.3 & 22.5 & 22.5 & NA \\
CHL-ADNA & 85.1 & 8.3 & 10.0 & 13.4 & 18.1 & 22.5 & 22.6 & NA \\
\hline
\end{tabular}

Table A2. Mean monthly temperatures in the tributary subbasins of the Chehalis River, southwestern Washington, summer 2014.

[Data for each subbasin are organized from downstream to upstream position. Location of each Site ID is shown in figure 1. NA indicates no data available either because logger was not installed, stolen, or data did not pass the initial data screening process]

\begin{tabular}{llccccccc}
\hline \multicolumn{1}{c}{ Subbasin } & \multicolumn{1}{c}{ Site ID } & March & April & May & June & July & August & September \\
\hline Black River & BLK-RT12 & 9.3 & 11.3 & 14.1 & 16.3 & 19.4 & 19.5 & NA \\
Newaukum River & NWK-MOUTH_TB & 8.2 & 10.1 & 13.3 & 16.4 & NA & NA & NA \\
Newaukum River & NEW-1 & NA & NA & NA & NA & NA & 21.4 & 17.7 \\
SF Chehalis River & SF-CHL-MOUTH_TB & 8.2 & 9.9 & 12.9 & 17.2 & 21.5 & 21.8 & NA \\
Elk Creek & ELK-CRK & 7.8 & 9.1 & 11.7 & 14.2 & 17.3 & 17.6 & NA \\
Upper Chehalis River & CHL-PEL-DS & 8.4 & 9.1 & 10.9 & 13.9 & 17.2 & 19.2 & NA \\
Upper Chehalis River & CHL-PEL-US_TB & 7.5 & 8.7 & 11.5 & 15.3 & 18.9 & 19.1 & NA \\
\hline
\end{tabular}


Table A3. Minimum monthly water temperatures in the main-stem Chehalis River, southwestern Washington, summer 2014.

[Data are organized from downstream to upstream position. Location of each Site ID is shown in figure 1. NA indicates no data were available either because logger was not installed, stolen, or data did not pass the initial data screening process]

\begin{tabular}{lcccccccc}
\hline \multicolumn{1}{c}{ Site ID } & River mile & March & April & May & June & July & August & September \\
\hline CHL-OAK & 45.2 & 7.5 & 8.8 & 10.5 & 15.1 & 18.1 & 18.5 & NA \\
CHL-US-BLK & 56.8 & 7.1 & 8.8 & 10.5 & 15.0 & 17.7 & 18.4 & NA \\
CHL-GLV_TB & 67.1 & 7.1 & 8.4 & 10.4 & 14.8 & NA & NA & NA \\
SCHEUBER & 74.6 & NA & NA & 13.5 & 15.2 & 18.5 & 20.6 & 15.5 \\
CHL-US-NWK & 79.0 & 6.7 & 8.3 & 9.9 & 15.0 & 18.1 & 19.8 & NA \\
CHL-ADNA & 85.1 & 6.2 & 8.1 & 9.6 & 14.4 & 17.4 & 19.4 & NA \\
\hline
\end{tabular}

Table A4. Minimum monthly water temperatures in the tributary subbasins of the Chehalis River, southwestern Washington, summer 2014.

[Data for each subbasin are organized from downstream to upstream position. Location of each Site ID is shown in figure 1. NA indicates no data were available either because logger was not installed, stolen, or data did not pass the initial data screening process]

\begin{tabular}{llccccccc}
\hline \multicolumn{1}{c}{ Subbasin } & \multicolumn{1}{c}{ Site ID } & March & April & May & June & July & August & September \\
\hline Black River & BLK-RT12 & 7.4 & 9.3 & 11.2 & 14.3 & 16.8 & 17.5 & NA \\
Newaukum River & NWK-MOUTH_TB & 6.2 & 8.1 & 9.3 & 8.5 & NA & NA & NA \\
Newaukum River & NEW-1 & NA & NA & NA & NA & NA & 17.5 & 14.1 \\
SF Chehalis River & SF-CHL-MOUTH_TB & 5.5 & 7.5 & 8.8 & 13.6 & 16.7 & 17.6 & NA \\
Elk Creek & ELK-CRK & 5.1 & 7.3 & 8.7 & 11.7 & 13.6 & 15.3 & NA \\
Upper Chehalis River & CHL-PEL-DS & 7.3 & 8.2 & 9.1 & 12.5 & 15.1 & 15.7 & NA \\
Upper Chehalis River & CHL-PEL-US_TB & 4.6 & 6.4 & 7.2 & 11.5 & 13.9 & 16.0 & NA \\
\hline
\end{tabular}


Table A5. Maximum monthly water temperatures in the main-stem Chehalis River, southwestern Washington, summer 2014.

[Data are organized from downstream to upstream position. Location of each Site ID is shown in figure 1. NA indicates no data were available either because logger was not installed, stolen, or data did not pass the initial data screening process]

\begin{tabular}{lcccccccc}
\hline \multicolumn{1}{c}{ Site ID } & River mile & March & April & May & June & July & August & September \\
\hline CHL-OAK & 45.2 & 10.1 & 14 & 17.4 & 20.3 & 24.5 & 24.5 & NA \\
CHL-US-BLK & 56.8 & 10.2 & 14 & 17.3 & 20.8 & 25.0 & 24.3 & NA \\
CHL-GLV_TB & 67.1 & 9.4 & 12.6 & 16.8 & 20.1 & NA & NA & NA \\
SCHEUBER & 74.6 & NA & NA & 16.4 & 20.3 & 25.3 & 25.1 & 21.4 \\
CHL-US-NWK & 79.0 & 9.8 & 12.9 & 17.6 & 21.1 & 25.9 & 25.2 & NA \\
CHL-ADNA & 85.1 & 9.7 & 13.0 & 18.1 & 21.6 & 27.0 & 26.3 & NA \\
\hline
\end{tabular}

Table A6. Maximum monthly water temperatures in the tributary subbasins of the Chehalis River, southwestern Washington, summer 2014.

[Data for each subbasin are organized from downstream to upstream position. Location of each Site ID is shown in figure 2. NA indicates no data were available either because logger was not installed, stolen, or data did not pass the initial data screening process]

\begin{tabular}{llccccccc}
\hline \multicolumn{1}{c}{ Subbasin } & \multicolumn{1}{c}{ Site ID } & March & April & May & June & July & August & September \\
\hline Black River & BLK-RT12 & 10.6 & 14.1 & 16.6 & 18.34 & 21.9 & 21.6 & NA \\
Newaukum River & NWK-MOUTH_TB & 10.1 & 13.4 & 17.2 & 24.12 & NA & NA & 0 \\
Newaukum River & NEW-1 & NA & NA & NA & NA & NA & 26 & 21.9 \\
SF Chehalis River & SF-CHL-MOUTH_TB & 10.6 & 13.8 & 18.0 & 21.5 & 26.1 & 26.1 & NA \\
Elk Creek & ELK-CRK & 9.1 & 12.9 & 14.9 & 17.53 & 20.6 & 20.6 & NA \\
Upper Chehalis River & CHL-PEL-DS & 9.5 & 10.2 & 12.7 & 15.46 & 23.7 & 24.7 & NA \\
Upper Chehalis River & CHL-PEL-US_TB & 9.5 & 13.5 & 17.4 & 20.17 & 23.6 & 22.7 & NA \\
\hline
\end{tabular}



Publishing support provided by the U.S. Geological Survey

Science Publishing Network, Tacoma Publishing Service Center

For more information concerning the research in this report, contact the Director, Western Fisheries Research Center U.S. Geological Survey

6505 NE 65th Street

Seattle, Washington 98115

http://wfrc.usgs.gov/ 
